\title{
Protests as "Events": The Symbolic Struggles in 2013 Demonstrations in Turkey and Brazil
}

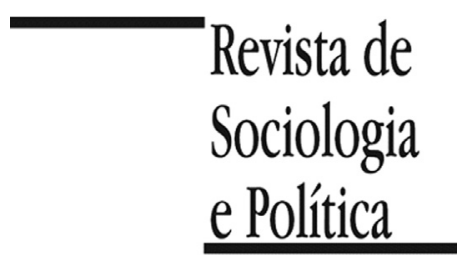

DOI 10.1590/1678987319276901

\author{
Ricardo Fabrino Mendonça'iid, Selen A. Ercan"iid, \\ Umut Ozguc ${ }^{\prime \prime \prime}$ iD, Stephanie Lorraine Gomes Reis ${ }^{\text {IV }}$ iDe \\ Paula Guimarães Simões $v$ (iD
}

ABSCTRACT Introduction: The concept of "event" offers a valuable lens to understand the discursive contestations in and around protests. Events create ruptures that disturb the logic of continuity and open up new way of thinking and talking about the past and the future. Drawing on this concept, this article analyzes the 2013 protests in Turkey and Brazil. It investigates how the causes of these protests were framed and debated in each country and how these frames shifted over time by opening up new interpretations of the past and the future. Materials and Methods: Data is generated from four Facebook pages capturing the messages posted during the first 30 days of protests in each country. In the Brazilian case, we collected the posts of: (1) Passe Livre São Paulo (301,787 likes), the group that started the wave of protests; and (2) O Gigante Acordou (155,690 likes), a collective that emerged during the protests, representing nationalist perspectives. In total, 626 posts were collected from both pages. In the Turkish case, we analyzed posts that appeared on the pages of : (1) Taksim Dayanismasi (82,479 likes), an association that played a significant role in organizing and mobilizing Gezi Park protests; and (2) Recep Tayyip Erdogan (6,957,408 likes), a pro-government and inherently anti-protest page. We coded each post inductively focusing particularly on the way they framed the causes of the protests. We then identified the number of times each frame was mentioned during the first 30 days of the protests and explored whether and how frames changed over time. Results: Our analysis reveals a significant shift in the way the causes of the protests were framed over time in both countries, yet with different implications. While in Brazil, we observe a frame transformation undermining the initial rationale of the protests, in Turkey we see a frame extension and the emergence of broader issues as the real causes of protests, such as the authoritarian nature of the regime and the restriction of democratic rights in this country. Discussion: The article offers a way of analysing protests based on a conceptual lens of event. It sheds light on the role of social media as a platform for symbolic struggles over the protests. Furthermore, the article opens up a debate about the developments of democracy in both countries.

KEYWORDS: events; protests; Gezi Park; June Journeys; Facebook.

Received in July 10, 2017. Revised in March 7, 2018. Accepted in May 27, 2018.

\section{Introduction ${ }^{1}$}

\footnotetext{
${ }^{1}$ This study was financed in part by the Coordenação de Aperfeiçoamento de Pessoal de Nível Superior - Brasil (CAPES) - Finance Code 001 (and Project 8881.130844/2016-01). We are also grateful to $\mathrm{CNPq}$ (305813/2017-0) and to Fapemig (APQ-01206-1) for their financial support. Lastly, we are thankful to the anonymous reviewers of the Revista de Sociologia e Política for their comments on this article.
}

$\mathrm{T}$ The recent wave of protests throughout the world has raised a series of questions and left many unanswered. What were the protests really about? How did they start? Were they foreseeable? Were they about small local issues or about the political or economic system as a whole? What political implications, if any, did they have? These questions rapidly spread on newspapers, television roundtables, scholarly books, everyday conversations, and online posts.

In this article, we take these questions as our starting points and interpret them as the manifestation of the concept of "event" in practice. In broader terms, events refer to ruptures in the ordinary flows of life (Quéré 2005). They usually displace the dominant constructions of reality and open up new ways of seeing and interpreting it. Events shape the way past is understood and the future is imagined. Events are not static occurrences with clear beginnings and endings: they evolve and always carry a potential to be updated at different moments and locations in the future (Deleuze \& Guattari 1994, p.158). As such, they offer a useful way of making sense of the protests. 
The concept of event has long been used in social and political theory, as well as in social movement studies (see, for example, McAdam \& Sewell 2001; Goodwin \& Jasper 2004; Della Porta 2008). These studies offer useful insights regarding when and how protest movements can be considered as events. Yet, in doing so, they focus mainly on the transformative dimension of events. According to Della Porta (2008), for instance, only certain protests bear eventful characteristics and have the potential to transform structures and collective identities. Rather than focusing on the transformative dimension of events, this article sheds light on another, equally significant dimension of events: the interpretive (hermeneutic) dimension, as manifested in the discursive contests and symbolic struggles they generate in the public sphere. Building on Mendonça (2007), we argue that protests can be considered events to the extent they represent ruptures. These ruptures open up spaces for interpretation and reinterpretation of the past and the future in new directions.

There are various factors that can enhance the interpretive dimension of protests and contribute to their characterisation as events. The use of social media platforms by protestors (and their opponents) is clearly one of them. There is a growing body of literature focusing on the central role of social media communications in the recent wave of protests (Poell \& Van Dijck 2018; Tufekci 2017; Papacharissi 2015; La Rosa 2014; Castells 2012; Bennett \& Segerberg 2013). These studies rightly indicate that the "real-time" nature of social media communications enhance the spectacle-form of media culture and thus influence the event dimension of the recent wave of protests (Poell \& Van Dijck 2018). They offer spaces to reflect, watch, listen, interpret, and communicate various aspects of the protests.

The article builds on these insights through a close analysis of social media communications during the 2013 protests in Brazil and Turkey. In doing so, the article uses the concept of event to make sense of the multiple and competing narratives and rationales about the protests. We focus on the online conversations about the protests on four Facebook pages during the first 30-days of the protests in both countries. We ask: How did they frame/explain the causes and rationalities behind the protests? How did the framing contestations evolve over time? Which frames were dominant? How were they related to the past and the future?

This study answers these questions and understands the complex web of interpretations (1) using the concept of "event" as its conceptual lens and (2) conducing a close analysis of the ways in which protests are communicated on Facebook pages. The analysis shows that the debates surrounding the 2013 protests revoked continuous reinterpretations of the past offering important implications for the future. What made the 2013 protests "eventful" is that, in both countries, the rupture caused by them led to a scene of uncertainty and opened up the stage for different political and social possibilities. As the time evolved, in both countries new issues came to the front stage. In Brazil, we observe a frame transformation regarding the reasons of the protests which ultimately undermined the initial focus of the demonstrators. In Turkey, the discursive contestations concerning the initial cause of the protests led to a frame extension and opened a space for broader democratic questions.

The article has five sections. First, we unpack the meaning of "event" focusing particularly on its political and interpretive (hermeneutic) dimensions. We discuss the relevance of the concept of event to the recent protest movements. The second section provides a brief description of the cases, the 2013 protests in Turkey and Brazil, and presents the key similarities between these two cases. The third section presents the data and the methods used to analyze four Facebook pages in light of the conceptual lens provided by the event. The fourth 
section presents the analysis of Facebook's posts, revealing the symbolic struggles and framing contests over the causes of the protests in both countries. Finally, in the fifth section we consider the overall implications of our findings for the future democratization movements in Turkey and Brazil.

\section{Events and their Interpretive Dimension}

An event can be understood as an occurrence that emerges in a certain context and introduces a discontinuity in the flow of experiences (Quéré 2005). Different meanings are produced around the same occurrence, and they are not merely correct or erroneous descriptions of a world that is already there. Rather, these meanings are a part of the event itself and they have important implications for the event's future developments. As such, events lead to framing contests over the definition of the event itself. As a part of this iterative meaning-making process, the frames employed to make sense of an event become part of the event themselves, opening different possible futures.

It is in this sense that an event constructs both its past and future (Quéré 1995; Zizek 2014). It is not that the past did not exist, but it only makes sense when it is re-narrated in present with its values and its interpretive frameworks. The November 2015 Paris attacks, for instance, threw a new light into past relations between the so-called Christian West and Islamic groups. The questions raised by the attacks opened up a different interpretation of the past relations: What caused the attacks? Which international geopolitical factors did really lead to the attacks? How were these attacks related to the colonial past of France? While the event builds its own past, it establishes new futures. New scenarios may emerge and disclose new possibilities: How should "the world" react to the attacks? Who should lead the process? Who is to be blamed? Are there relationships between the event and immigration policies? By instantly disclosing the contingency of the world and its future, the rupture generated by the event posesABSTRACTmoral inquiries and everyday pragmatic questions to society. In reconstructing the past and opening up new futures, events prove to have a hermeneutic power (Quéré 2005).

Events are thus inherently political: they trigger new disputes and new narratives of the past and the future, affecting their present developments. They trigger reactions and responses from individuals and evoke the need to reestablish the continuous flow of experience demanding the normalization of the event (Quéré 2005). While it may look like a rupture at first sight, the normalization process turns the event into something perfectly explainable, on the basis of causes "already there" and other past occurrences. In this sense, events do foster collective meaning-making process around thorny questions, which are usually pushed aside by the inertia of the existing order. Events act as cracks that make the world contingent again, calling for human action. Even if the steps to be taken may seem as the only real possibilities, they were produced by actual actions within a given context. Such actions are not entirely chosen nor determined by pre-existing structures. Rather, they are the products of an interchange between individuals and their historical, social, cultural, and institutional contexts.

The interpretive (hermeneutic) dimension of events has already been discussed in a wide range of studies. In the early 1900s, American Pragmatists used it to discuss the contingency of reality and its moral and political implications. Mead used the concept to highlight the centrality of haphazard in human experiences and the temporal dimension of these experiences (Joas 1997). As Mead (1932, p.32) put it, an event "creates with its uniqueness a past and a future. As soon as we view it, it becomes a history and a prophecy." Dewey further developed the political dimension of events. An event is an emergence in a 
given context that must be described and narrated in order to be re-incorporated into the flow of experience (Dewey 1993). For Dewey (1954), events can be problematic situations, whose rupture demands reflexivity and a collective quest for solutions through democratic conversation.

The political dimension of events was also highlighted by Arendt (1993) a few decades later. For Arendt, some occurrences are so overwhelmingly unexplainable that they displace our established interpretive frameworks. The Nazi totalitarianism regime, for instance, was something not only new, but something that demanded new categories of thought to render the world comprehensible. Events, for Arendt, shed light on the ruin of our categories of thought and judgments (Arendt 1993, p.49). At the same time, they set the end of processes; they are the result of a thread that reconstructs its own past.

Since the 1970s, the political dimension of events has received increasing attention in French academy. Foucault (2007) employed it to define the orders of discourse. Historian Nora (1988) investigated how the mass media fostered monstrous events that acquired unthinkable dimension. Mouillaud (2002) and Charaudeau (1997) also discussed the role of the media in the construction of events, pointing to the way that framing restricts un-catchable experiences in order to make them apprehensible through discourse. In media studies, Dayan and Katz (1994) analyzed the visibility of public ceremonies and rituals, arguing that media events transform the world.

Poststructuralists have also made crucial contributions to the development of the political dimension of the concept. From Deleuze (1975) to Badiou (1994), the concept has been used to discuss the role of the unpredictable in social life. Zizek (2014) has used the concept of event to elaborate how recent uprisings displace current frames. Events are essentially political. By changing the past, they reinvent who we are and may become.

The literature on social movements also utilizes the concept of events. Very often, the word "event" is employed to refer to episodes of contention. Accornero and Pinto (2015), for example, advocate the Protest Event Analysis (PEA), but do not use "event" as a concept, rather mobilize it as a word to refer to episodes of contention. As noted above, more frequently social movements scholars focus on the transformative dimension of the events. The idea of Transformative Events, proposed by McAdam and Sewell (2001) and adopted by Goodwin and Jasper (2004) and Della Porta (2008), suggests that only certain events (protests) "can produce radical turning points in collective action" (Goodwin \& Jasper 2004, p.246). Transformative events open new possibilities for agency. McAdam and Sewell (2001) deal with the centrality of time to discuss political contention and criticize the way in which political science tends to ignore this dimension by building time series that equalize events.

Building on Mendonça (2007) and Cefaï (2007; 2017) we emphasize the hermeneutic power of the events. Following Mendonça (2007), in particular, we argue that protests can be considered as events, to the extent they represent ruptures and foster the reinterpretation of the past and the future, while opening up a space for new political possibilities. When seen in this light, protests can be seen as political struggles over meaning, affecting the way we interpret and experience the past and the future in the present. It is important to highlight that we do not employ the concept to distinguish certain episodes from other events. Similarly, we do not take the concept of event as a descriptive or a normative tool to be tested by the reality. Rather, we use it as a theoretical lens to make sense of the 2013 protests in Turkey and Brazil. This allows us to look at social phenomena in a particular way, comprehending how they unfold in time and space, and building a complex realism that encompasses interpretations within the definition of reality. The concept leads to a particular way of looking at real- 
ity that sees occurrences spread over time and space, in doing so, it help us to understand how re-interpretation of reality affects its future developments.

\section{Background: 2013 Protests in Turkey and Brazil}

${ }^{2}$ Barría (2018) shows how the recent cycle of protests pervades not only (or mainly) democratic contexts but also authoritarian regimes.

\footnotetext{
${ }^{3}$ The Confederations" Cup is a rehearsal of the Football World Cup that were held in the following year. The Confederations" Cup happened in June 2013, bringing world attention to Brazil.
}

The early $21^{\text {st }}$ century has witnessed a re-emergence of contentious politics worldwide in disparate parts of the globe including Turkey and Brazil (Della Porta 2017). ${ }^{2}$ The Turkish protests began on 29 May 2013 in Taksim Square in Istanbul as a response to government's decision to build a new shopping mall and residential complex on the grounds of a historically significant public park (Gezi Park). On 30 May, police in Istanbul broke up a small demonstration at Gezi Park using tear gas and burning their tents. What began as a peaceful environmentalist protest quickly exploded into massive resistance, and it spread to many other cities against the Justice and Development Party (JDP), or more specifically its leader, then Prime Minister Erdogan. The brutal police reaction to peaceful protest transformed the nature of the protest within a couple of days. Protests changed from a local development issue to wider protests across Turkey about a broad range of issues including government encroachment on freedom of speech and Erdogan's increasing authoritarianism. By 31 May, tens of thousands were clashing with police units in different districts of Istanbul and hundreds of protesters were under police custody (Amnesty International 2013).

Around the same time, in Brazil, a complex process of massive protests emerged with Free Fare Movement calling citizens to march against the rise of public transportation fares in São Paulo in the beginning of June 2013 (Judensnaider et al., 2013; Maricato et al., 2013; Ricci \& Arley 2014; Singer 2014; Gohn 2014; Scherer-Warren 2014; Bringel \& Pleyers 2015; França \& Bernardes 2016; Mendonça 2017; Bringel 2017). Police brutality, the visibility of the controversial Confederations" Cup, ${ }^{3}$ growing indignation with public expenditures and the political system, and a shift in the media coverage (from de-legitimation to support) are some of the key factors that enlarged the scale of the protests (Nogueira 2013; Nobre 2013; Ricci \& Arley 2014). Fare increases were revoked in São Paulo on June 19, but the protests kept intense at least until the end of June and reached their climax on June 20, when more than two million Brazilians were on the streets in hundreds of cities and towns.

There are many similarities between these two protests which make their comparison particularly interesting. First, the demonstrations, in both countries, were almost simultaneous. They are considered to be part of an ongoing cycle of global protests, utilizing tactics and performances previously used in protests such as the Arab Spring, the Indignados and the Occupy. Second, despite their huge cultural and political differences, Brazil and Turkey share a history of political instabilities, and the 2013 protests lead to years of growing authoritarianism. Third, in 2013 both countries experienced economic growth and stability, and the protests were not preceded by an economic crisis or by the implementation of austerity policies as it was the case with other countries (Della Porta 2017). Finally, the 2013 protests in Brazil and Turkey were strongly marked by political disputes over the actual meaning of what was going on and such struggles had political implications in the developments following the protests.

The third factor seems to differentiate these countries from the contexts of most of the other protests composing the broader cycle in which they are inserted. Most of the literature on the wave of mobilizations that took place in the first two decades of the $21^{\text {st }}$ century emphasizes how they tend to share two common elements (Della Porta 2015; Accornero \& Pinto 2015; Offe 2013; Ortiz et al., 2013; Tejerina \& Perugorría 2012): (1) a frontal contestation to the political elites (and to the political system and representation broadly speaking); 
and (2) a refusal of austerity policies in the context of a crisis (Rüdig \& Karyotis 2013). The first element also applies to Brazil and Turkey. Interestingly, however, the second one does not, as both countries were experiencing a period of economic expansion, and austerity policies were not yet on the agenda (although they began to emerge in the following years). In Brazil, for instance, many protesters claimed for budgetary control in the face of the enormous public expenditures with mega-events such as the World Cup and the Olympic Games.

In both Brazil and Turkey, protests varied significantly in their form and content, not only across cities and time, but also within each city and each protest. In both countries, these massive movements led to symbolic struggles and the emergence of conflicting meanings, what is an expected part of their characterization as events. These struggles shaped not only the actual practices, but also the consequences and developments of the protests. Symbolic struggles can be defined as social processes that are characterized by disputes around the definition of what is actually happening. In both Brazil and Turkey, the contradictory ways through which the protests were understood and framed were at the kernel of their developments. In both countries, there were lively debates over the actual causes of these processes. Different interpretations saw different pasts as evident, turning the unexpected and displacing occurrences into perfectly comprehensible narratives. As we elaborate further below, these debates took the protests in different directions.

Although the symbolic struggles took place in various forms and in a diverse range of arenas, this study focuses on social media platforms and especially the online communications on Facebook. Our focus on Facebook as a platform for discursive contestation is justified by the platform's relevance throughout the protests in both countries. The extensive use of social media, in particular Facebook and Twitter, during the recent wave of protests has been studied from different perspectives, and in fact, there is now an established scholarship that recognizes the distinctive role of social media in political mobilization and in creating non-traditional political platforms for civic engagement (Harlow \& Harp 2012; Castells 2012; Bennett \& Segerberg 2013; Warren, Sulaiman \& Jaafar 2014; La Rosa 2014; Wojcieszak \& Smith 2014; Theocharis et al., 2015; Milan 2015; Tufekci 2017). These studies have showed that social media helps to "assemble masses of individuals" onsite, enabling a new form of participatory politics that transcends class, gender, ethnic, and ideological boundaries, and the hierarchical structures of "old" social movements (Juris 2012). By creating "digitally mediated networks", social media blurs the distinction between real and virtual and online and onsite activisms, and in many cases, it bridges these distinct spheres (Ratto \& Boler 2014, p.23).

The use of social media during the 2013 protest movements in Turkey and Brazil has also been discussed extensively both in the media and in many scholarly works. Gomes (2016), for instance defines the social networking sites in the Brazilian demonstrations as the new arenas and structures of political struggles. Malini et al. (2016) investigate the hashtag \#vemprarua in 2013 and look at both texts and images stressing the engagement around it in Brazil. Araújo, Penteado and Santos (2015) and Segurado (2015) also emphasize the use of SNS for mobilization in the 2013 protests. Researchers have also devoted attention to online controversies about violence in the demonstrations (D'Andréa \& Ziller 2014; Pereira \& Santos 2016) and to the alternative coverage generated by media activism in Brazil (Pennini \& Barros 2015; Tosetto 2015)

Similarly, in the Turkish case, social media played a significant role. It helped to mobilise the protestors in large numbers and enabled the movement to take a pluralistic and an inclusive shape (Tufekci 2017). Many scholars have ex- 
amined the widespread use of social media during the course of events (see, for example, Demirhan 2014; Farro \& Demirhisar 2014; Mercea et al., 2017; Odabas \& Reynolds-Stenson 2017). The existing research suggests that social media provided an alternative media platform by disseminating information about the protests while mainstream media was silenced (Ozturkcan et al., 2017). Twitter has been particularly influential in facilitating information sharing (Demirhan 2014). While the use of social media did not produce radical outcomes, it increased international awareness on the ongoing police repression in Turkey and alarming use of tear gas during peaceful protests (Guner 2016).

In this article, we are interested in social media as a communication platform that enables symbolic struggles over the causes of these protests and enriches the hermeneutic power of protests as events. As such, our research contributes to the existing scholarship on the role of social media in social movements in a number of ways. First, various studies on the Brazilian and Turkish cases mainly focus on the functions of social media in mobilizing the protestors. Our study, however, examines the discursive contestations over the meaning of the protests on social media and analyzes how such contestations contributed to either frame transformations or frame extensions. Second, our focus on "frame analysis" reveals the ways in which social media contributed to the "eventual" dimension of meaning and shows how these symbolic struggles over the meaning of these protests took place on online platforms. Finally, we do not look at these pages to find a coherent and fixed way to frame the phenomena. Instead, we seek to grasp the transformations in narratives across time as a component of the phenomena in itself.

\section{Data and Methods}

\footnotetext{
${ }^{4}$ It is important to mention that we have also attempted to collect data from AnonymousBR, which had a central role in the online discursive flows during the protests. However, the number of posts on this page was so high that Facebook does no longer retrieve posts from a significant part of June 2013 , obliging the study to discard them.
}

The analysis scrutinizes the ways the symbolic struggles played out in four selected Facebook pages - two divergent pages for each country during the 2013 protests. For each page, we collected and analyzed the posts during the first 30 days of the protests. In the Brazilian case, we collected the posts of (1) Free Fare São Paulo ["Passe Livre São Paulo"] (301,787 likes), the group that started the wave of protests; and (2) The Giant Awoke ["O gigante acordou"] (155,690 likes), the group that emerged during the protests in mid-June, representing nationalist stances. ${ }^{4}$ During the 30 -days period (between 1 and 30 June), we found 626 posts in total on both pages: 242 in Free Fare Sao Paulo (MPL) and 384 in The Giant Awoke (OGA).

In the Turkish case, we analyzed the posts that appeared on the Facebook page of (1) Taksim Solidarity (TS) [Taksim Dayanismasi] (82,479 likes), an association that played a significant role in the organization and mobilization of the mass protest movements, and those of (2) Recep Tayyip Erdogan (RTE), a pro-government, anti-protest site $(6,957,408$ likes). In the course of 30 days (28 May to 28 June 2013), we found a total number of 437 posts in both pages (397 in TS and 40 posts in RTE).

We have examined each post focusing particularly on the way they framed the causes of the protests. Frame analysis is a method extensively used in various ways and with diverse purposes (Goffman 1986; Entman 1993; Chong \& Druckman 2007; Mendonça \& Simões 2012). It helps us to understand how actors make sense of the context in which they find themselves. Frame analysis offers interpretive procedures to reconstruct meaning from the lenses of those involved.

A frame is a particular way of classifying information that enables people to make sense, relate and label everyday occurrences in a particular way (Goffman 1974). In this sense, "to frame is to select some aspects of perceived reality and 
${ }^{5}$ For other key references on this topic, see also: Gitlin (1980); Gamson \& Modigliani (1989); Gamson (1992); McAdam (1996). make them more salient in a communicating text, in such a way as to promote a particular problem definition, [and] causal interpretation" (Entman 1993, p.52). Social movement studies have made frequent use of frame analysis in order to understand the interpretive dynamics of political mobilization and of their social struggles (Benford \& Snow 2000). ${ }^{5}$ Snow et al. (1986) provide an influential typology for the studies of political contention, when they investigate the centrality of frame alignment for political engagement. They claim that frame bridging, frame amplification, frame extension and frame transformation are frequent strategies in the quest to strengthen the mobilization processes.

We focused on content communicated in four selected Facebook pages during the first 30 days of protests. We coded each Facebook post taking into account analytical categories and themes concerning how the causes of the protests were framed in each post. We then identified the frequency of each frame during the first 30 days of protests, and determine the change in the frequency. This type of in-depth analysis allowed us to observe the dynamic symbolic struggles over the interpretation of the causes of the protests, showing how the lines of causality are not just out there to be found, but always subject to the interpretation and re-interpretation of the actors involved in these events. By seeking the root causes of the protests in the past (and thus reconstructing the past), the protestors also proposed imagining the future in new ways.

\section{Analysis: Symbolic struggles over the causes of protests in Brazil and Turkey}

\section{V.1. The Case of Brazilian Protests: Transportation vs Corruption}

The Brazilian data shows clear symbolic struggles over different meanings attached to the protests. In the quest to explain the events while they were still happening, the actors engaged in the protests attempted to define what the struggles were about. A long list of issues were mentioned in Facebook posts in order to explain the causes. As the Chart 1 shows, the topic of public transportation and fares dominated the posts.

Despite the preponderance of a particular cause that emerged in the Facebook posts, one can gain a more nuanced understanding of the possible rise and fall of particular causes by looking at this data across time. Chart 2 shows that the issue of public transportation and fares remains unchallenged until June 13, when the topic of police violence gains traction as an explanation for the protests. It should be noted that June 13 was a turning point in the Brazilian protests, as the police violence was broadly covered by the media and discussed by protestors.

More interestingly, the Chart 2 shows a complete change after June 17 . The Facebook page "O Gigante Acordou" (OGA) was also created on June 17. Our data from the initial 16 days include only the posts from "Passe Livre São Paulo" (MPL), which was managed by the movement that triggered the protests. In contrast to MPL, OGA was not managed by a pre-existent movement. The posts published on OGA's page were more diverse, yet it is possible to notice a strong focus on two aspects of the posts. First, there are two peaks of posts that express criticisms against political actors and institutions, most of them denouncing the practice of corruption. Second, many posts are declarative: they make claims about a variety of themes, which this study aggregated under the umbrella of rights, such as health, education, and housing. Chart 3 shows the differences between the key issues on two Facebook pages during the first 30 days of the protests.

Our analysis of these posts suggests that the Facebook pages fostered diverse approaches in their framing of the causes of the protests. "O Gigante 
Chart 1 - Frequency of issues on MPL and OGA Facebook pages between June 1-30, 2013

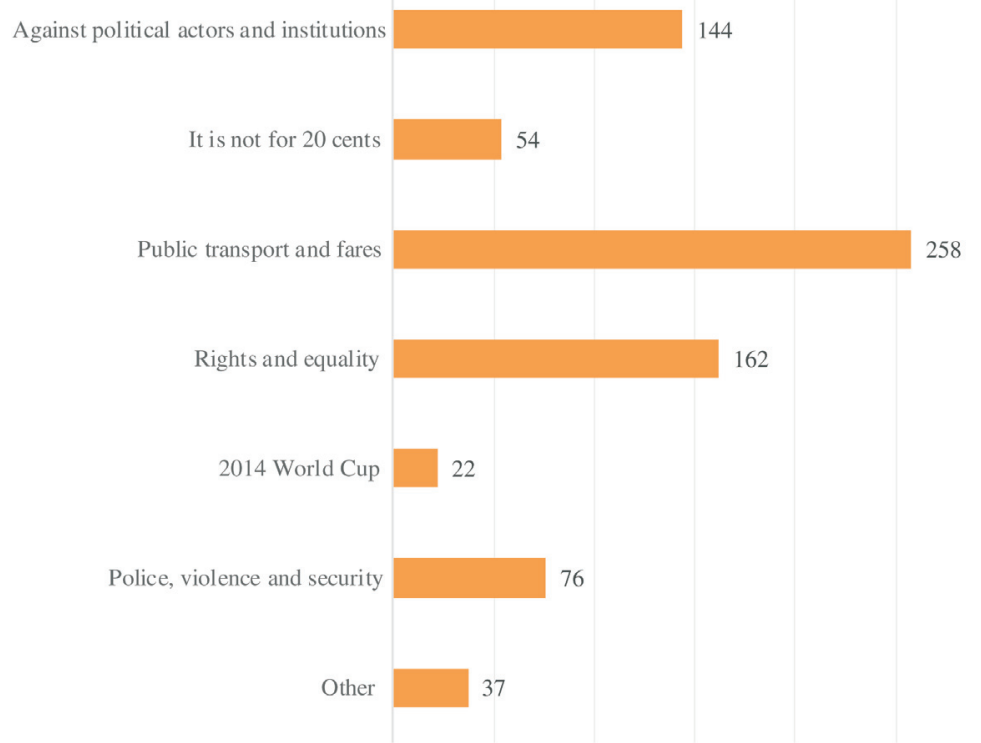

Source: Protests and Political Engagement Research Project.

Chart 2 - Frequency of issues mentioned in MPL and OGA Facebook pages between June 1-30, 2013

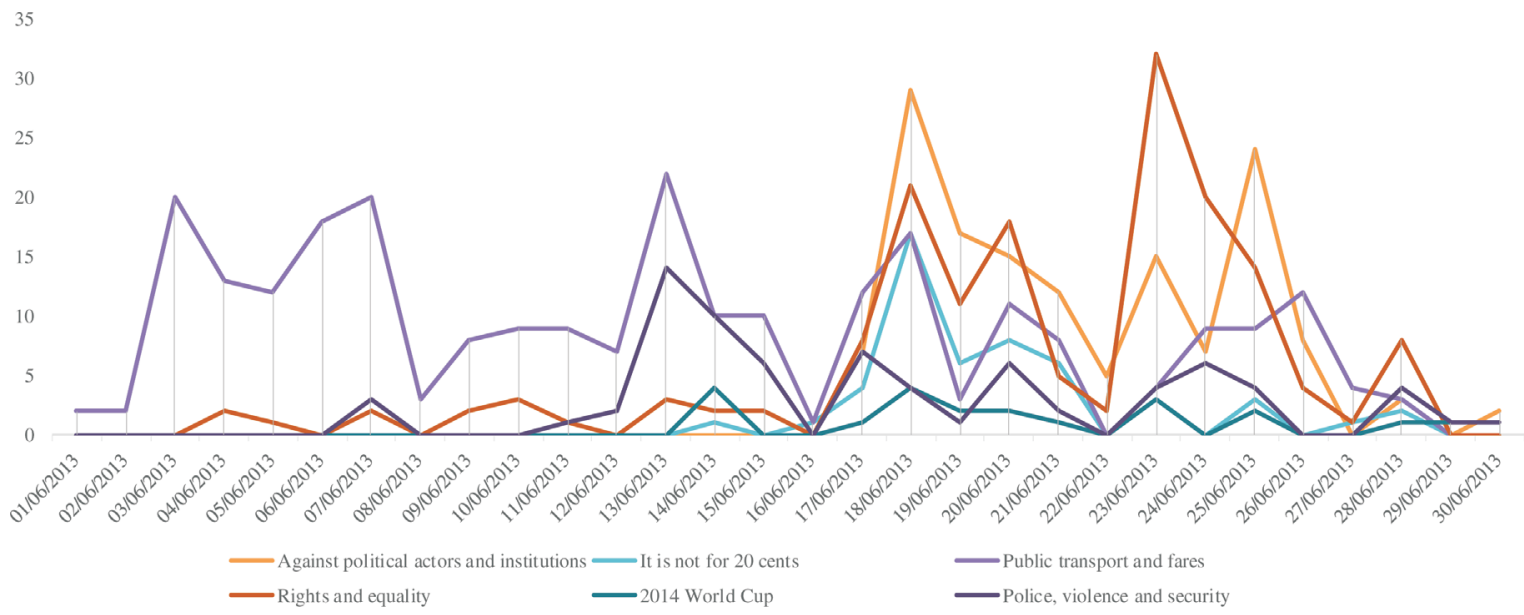

Source: Protests and Political Engagement Research Project.

${ }^{6}$ Despite the fact that the posts from $O G A$ started only on June 17, our data collection has more posts from this page than from MPL.
Acordou" employs a more diverse narrative, while, in the "Passe Livre São Paulo", it is possible to identify one particularly dominant cause: public transportation and fares constitute $62 \%$ of the causes stated. ${ }^{6}$ Chart 4 adds one more layer to this difference by presenting the distribution of the three prevalent issues across time.

The symbolic struggles enveloping the protests became clearer as the protests evolved. On the one hand, we observe that the MPL which triggered marches was motivated particularly by the issue of fares and public transportation. On the other hand, we see that the $O G A$ explicitly challenged the centrality of transportation fares (claiming "It is not for 20 cents") and developed a more 
Chart 3 - Distribution of issues mentioned in MPL and OGA Facebook pages between June 1-30, 2013

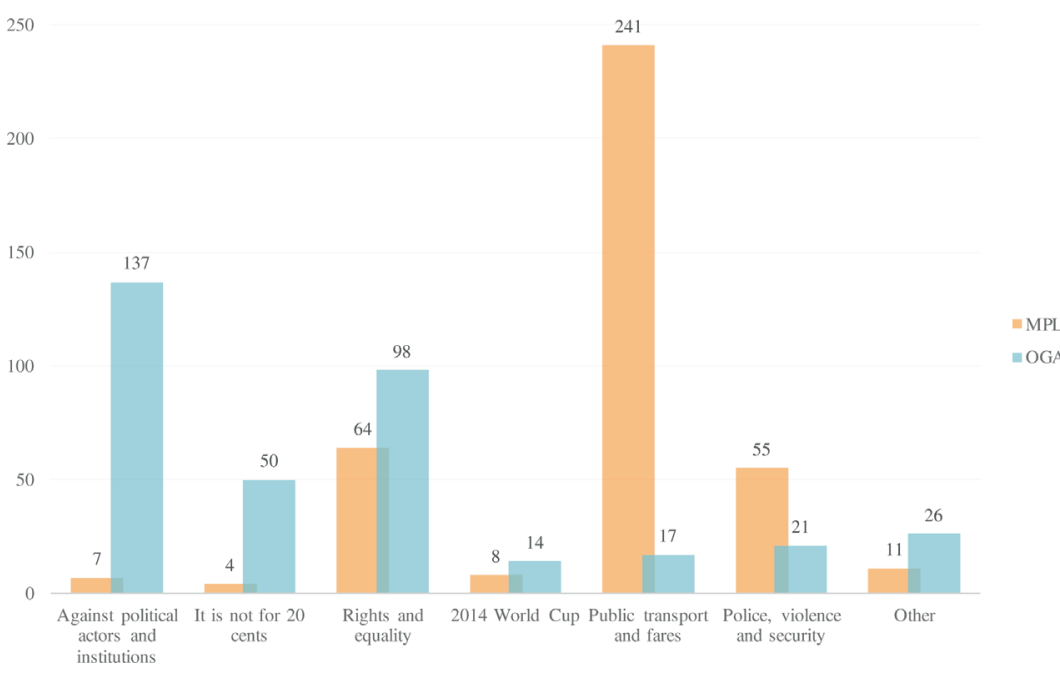

Source: Protests and Political Engagement Research Project.

diverse agenda and discourse against politicians and the existing political system. It also highlighted many other social illnesses and injustices.

A qualitative analysis of the posts sheds further light on the way this symbolic struggle actually occurred. The MPL's focus became evident in some of its first posts in June, when the movement called for protests in many neighborhoods.

Chart 4 - Distribution of three prevalent issues mentioned in MPL and OGA Facebook pages between June 1-30, 2013

35

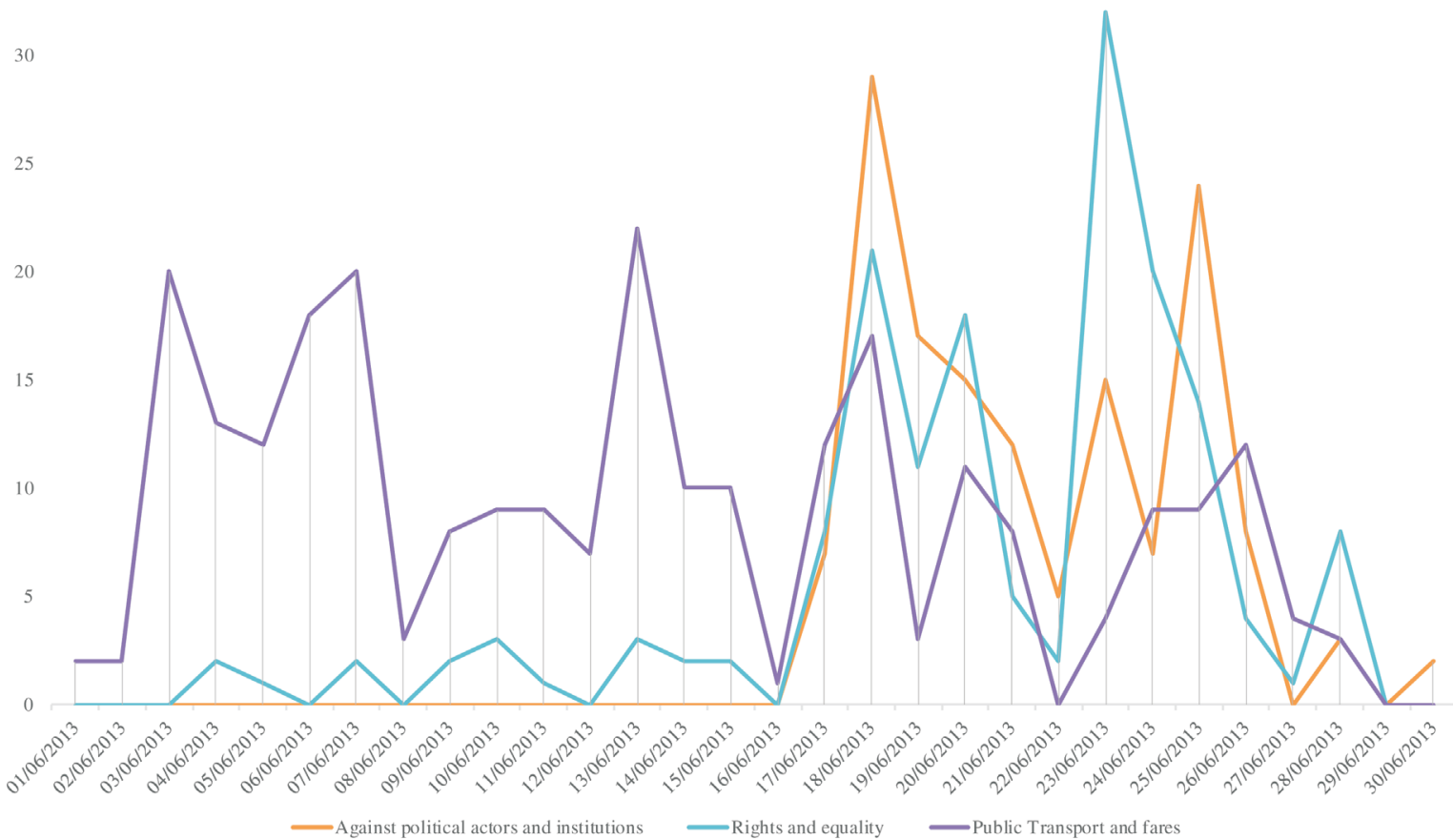

Source: Protests and Political Engagement Research Project. 
“Tomorrow our trouble increases to R\$3.20! Everybody against this robbery! BIG PROTEST AGAINST FARE RISE - 06/06 -5 P.M. [...] The mayor has confirmed that bus fares will increase in the beginning of June to $R \$ 3.20$. [...] Every time fares rise, the number of people excluded from the transportation system also grows - in 2010, there were already 37 million Brazilians that did not take the bus every day because they could not afford it. Not having access to transportation means not accessing the city. [...] IF THE FARES INCREASE, THE CITY WILL STOP! EVERY RISE IS AN INJUSTICE!'

The posts published by the MPL in the first days of June mainly attempted to mobilize people. In Gamson's (1992) typology, these posts tried to show an injustice, leading directly to a call for action. In order to do so, they repeatedly invited people to future marches and showed the strength of the ongoing struggle.

"Attention everybody!!!

NEW DEMONSTRATION AGAINST THE FARE RISE IS SCHEDULED FOR TOMORROW (FRIDAY, JUNE 7). MEETING POINT AT LARGO DO BATATA (PINHEIROS), 5 P.M. TODAY, THERE WERE 5 THOUSAND IN THE STREETS. TOMORROW WILL BE BIGGER!!” (MPL, June 6, 2013).

The posts often showed images and videos from previous protests or news articles that gave visibility to the demonstrations. Many images exhibited bus turnstiles on fire or catchphrases such as " $\mathrm{R} \$ 3.20$ is robbery!" (Figure 1).

As the protests got bigger and spread over the country, the MPL sought to emphasize the focused agenda that steered their struggles:

"This is a broad and popular struggle with one sole, clear and simple demand: the reduction of bus fares from $R \$ 3.20$ to $R \$ 3.00$. This is what people in the streets are demanding" (MPL, June 11, 2013).

A post published one day later, on June 12, reproduced an online article that showed the impact of the fare rise in the lives of many people. According to the article, many poor people had to skip some of their meals in order to afford the costs of public transportation. MPL's focus on the price expanded as the protests were repressed by the police. State violence became one important motive

Figure 1 - Picture of demonstrators in the city of São Paulo burning turnstiles made of card boxes. The banner on the back of the image states: "If the fares are not reduced, São Paulo will stop!"

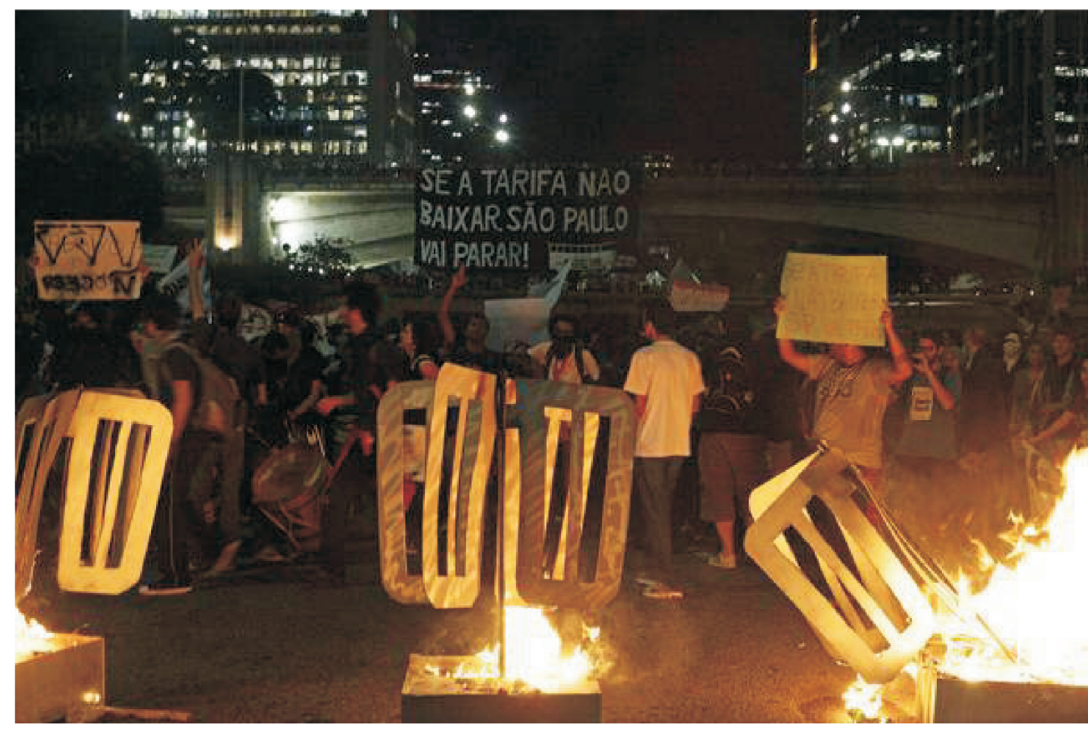

Source: Image posted on MPL's Facebook page (June 07 2013). 
to go to the streets, and several posts reported the arbitrariness of detentions and the class dimension of police violence.

"The truculence of the police and the selectivity of Justice - which distinguishes poor and rich, people that demonstrate in defense of rights and business persons - will not stop the continuity of our struggle. Police repression is the everyday life of the excluded people of this city and we will never shut up in face of it. [...]" (MPL, June 13, 2013).

The public statement of this "cause" (i.e. police brutality) became stronger in MPL's Facebook narratives after June 13, when the repression was particularly strong (and covered by the mass media).

"We are watching regrettable episodes of police repression, which turned São Paulo downtown into a battlefield. The $4^{\text {th }}$ great march against fare rises was peaceful and had more than 10 thousand people, when, around Roosevelt Square, a brutal police repression took place. Demonstrators tried to reorganize themselves, and the shock troops and the cavalry kept using stun bombs, rubber bullets and tear gas. They are the ones responsible for this chaos in the city, not us. We are in the streets, protesting in a legitimate way, against the segregating rise of fares" (MPL, June 13, 2013).

Many posts asked protesters to send pictures and reports of aggressions they had suffered. Other posts reported the situation of those arrested and the actions taken by the lawyers of the movement.

The symbolic struggles on the causes of the protests became clear as they spread and other actors including Facebook pages started talking about it. On June 17, the posts of OGA began fostering a very different explanation of the protests which invited people to fight against corruption and political actors. $O G A$ 's posts were much more frequently based on images and in most cases they were not developed around broader arguments (Figure 2).

The meme clearly states that the struggle cannot be framed as "due to 20 cents" and it pushes another agenda: inadequate public expenditure and corruption. The "cause" should involve a broader agenda that targets political actors and the political system. It also involves the poor quality of public services, such as health and education. While the MPL insisted on the issue of fare rises and

Figure 2 - Guy Fawkes' mask with the sentences: "It is no longer about 20 cents" and "Now we want the 80 billion back"

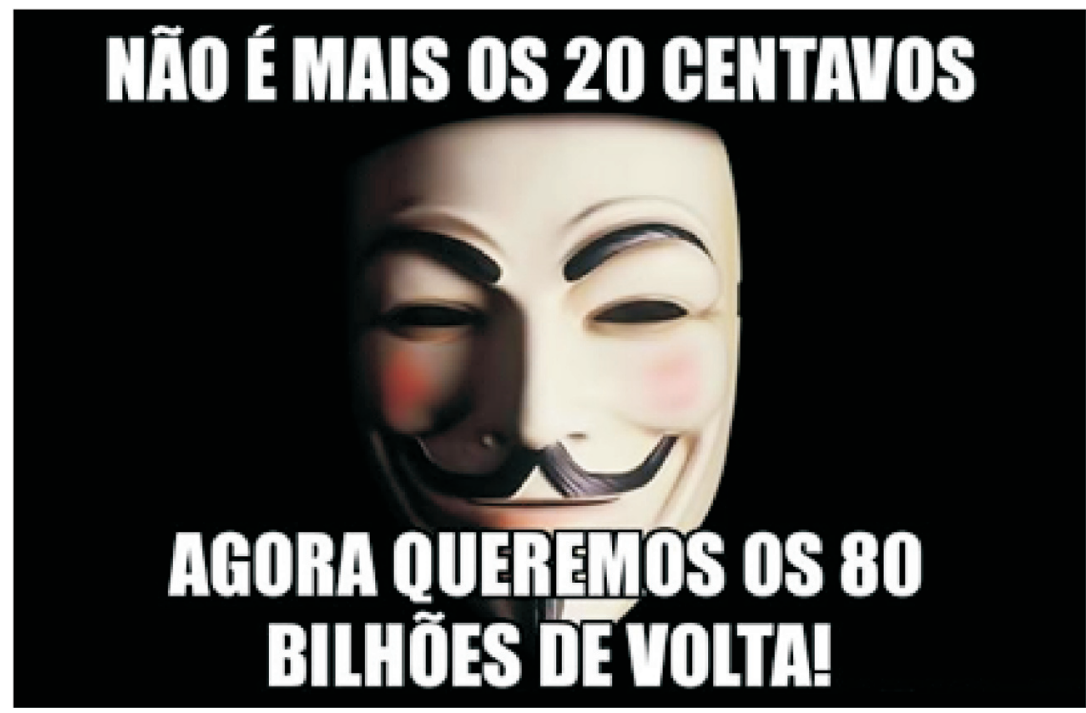

Source: Image posted on OGA's Facebook page (June 17 2013). 
public transportation, $O G A$ framed the 20 -cent rise as a tiny element in a universe of "more important" issues (Figure 3).

The metaphor of the "water drop" was used to claim that what triggered the protests was not its actual cause. It was simply the "last drop" that made the country's outrage spill. Many posts published on $O G A$ 's page show the streets filled with demonstrators, arguing that the country had finally realized the low quality of public services, corruption, and self-interest of those in power and awakened (Figure 4).

At the same time that $O G A$ was trying to broaden the agenda of protests, the MPL was tenaciously sustaining the "cause" of public transportation and its fares. On June 19, the mayor and the governor of São Paulo revoked the fare increase. The MPL celebrated the reduction, but, at the same time, it emphasized

Figure 3 - A Glass full of words: Violence, Corruption, Neglect, Lack of Education, Cronyism, and Inflation. On top, a drop of 20 cents.

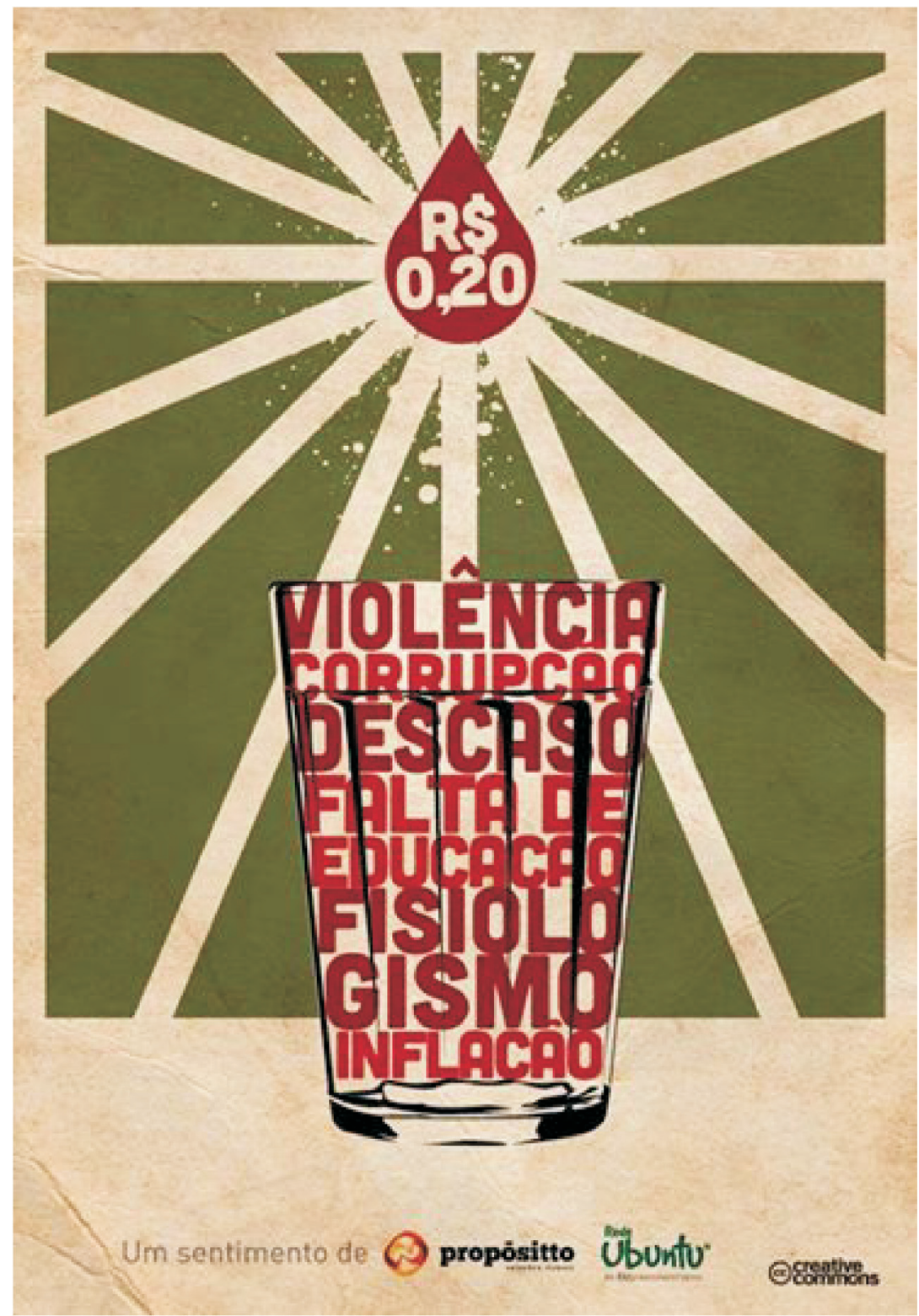

Source: Image posted on OGA's Facebook page (June 18 2013). 
Figure 4 - Picture of a classroom (left) and picture of a stadium (right) in the same state. In the bottom, the following sentence: "And they still ask why protests"

\section{\#Escola em Pernambuco}

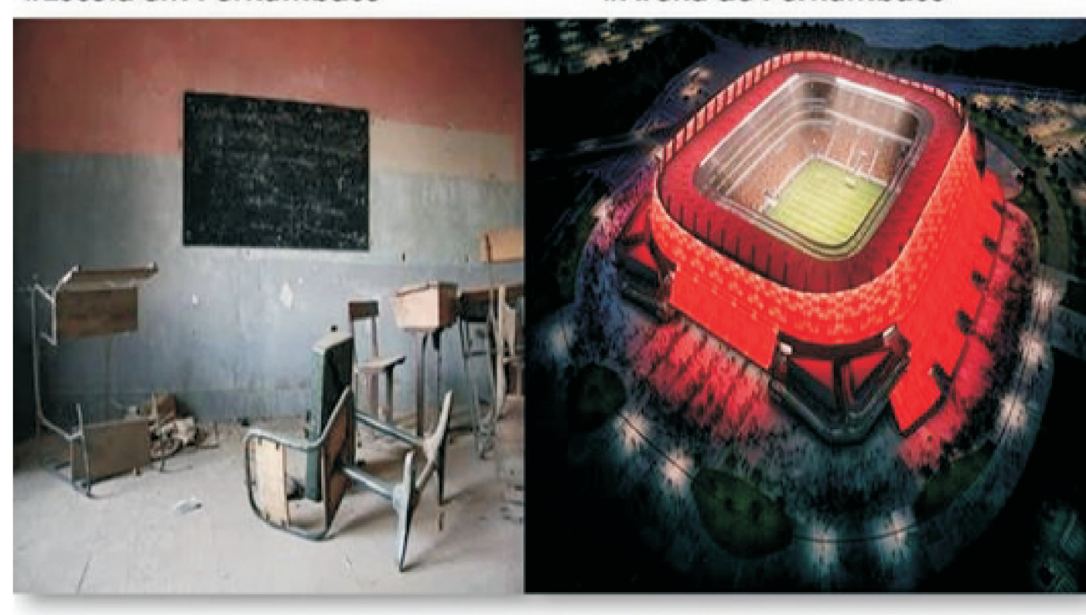

\section{E ainda perguntam porque os protestos...}

that the struggle around transportation had to continue. The movement also reinforced the agenda of state violence and emphasized the idea of a "life without turnstiles".

"The city will never forget what has happened in the last weeks. We have learnt that only the struggle from below can defeat the interests from above. [...] The route followed by the Free Fare Movement does not start or finish today. It continues towards a free public transportation, where decisions are taken by the users and not by politicians and business persons. [...] For a life without turnstiles! [...]" (MPL, June 20, 2013).

The comprehension of the strategy of sustaining the focus on public transportation required attention to the broader political context in which the protests occurred. The MPL is a leftist progressive movement that is not aligned with any political party. It had been pushing the agenda of free public transportation for at least eight years when the protests emerged. When the protests spread quickly, the movement perceived the risk of a shift in the agenda. Several demonstrators associated their presence in the streets to challenge the Workers" Party (PT) that had been ruling the country since 2003. They saw the protests as a way to publicly state their outrage against corruption cases that were going to be discussed by the Supreme Court in that same year. Empowered by the discourse of the crisis of representative democracy, they adopted a nationalist tone to "clean" the country of parties and politicians. The MPL did not want to see itself linked to these discourses. They did not present themselves against the Workers" Party (even if they did not support it), or raised flags against parties as a whole. The MPL did not support the diffuse anti-party discourse.

At the same time, however, the MPL was part of the political struggles that criticized the current practices of representative democracies and the permanent denial of the "right to the city". Evidently, the movement did not deny the importance of education and health or the criticism of representatives. The point was that these topics were framed in different ways and they were expressed through the metaphor of a "city without turnstiles". The idea was to show that 
the right to the city encompassed several rights and freedom of movement throughout the city was one of them.

"The struggle for the Free Fare is essential to assure access to public transportation. However, it is also essential because access to transportation means access to other rights: the school, the hospital, the theater. It thus unifies all social struggles. [...]

According to the National Association of Urban Transportation Companies, 37 million Brazilians do not have money to pay for fares regularly. This means that they are excluded not only from transportation, but of all other rights. The turnstile that segregates people is not only on buses. The city is full of turnstiles, many of them invisible, obstructing the access to health, education, sports, leisure, other neighborhoods, downtown" (MPL's Booklet, pp.3-4, Facebook, June, 25 2013)

The MPL's struggle was against the obstacles, expressed by the metaphor of "turnstile", which denied opportunities and rights to poor citizens. A life without turnstiles depends, they argued, on a broad struggle against the segregation generated by transportation fares. Such discursive frame helped the MPL to relate its demands to the broader agenda circulated within the public sphere without losing its focus. It also helped the MPL to rebut a criticism directed to them for their insistence in the initial cause. A post from $O G A$ published a few days earlier illustrates this criticism:

\begin{abstract}
"Once upon a time, there was the Free Fare Movement, a movement with half a dozen communists that unintentionally has been able to trigger the outrage of all social classes. They have sold themselves and stopped. THE END! THE GIANT IS AWAKE AND WILL GO ALL THE WAY THROUGH SO THAT BRAZIL BECOMES A JUST COUNTRY!"
\end{abstract}

Through the metaphor of the "city without turnstiles" the movement linked its focus to a broader agenda of rights, claiming to be struggling for a just society and challenging the argument that it had given up. It attempted to show how the "cause" it attributed to the protests encompassed many other causes, without becoming a loose cannon. It used frame bridging, in Snow et al. (1986) terms, in order to link the original demand to other claims and feelings publicly expressed along the protests. However, in the symbolic struggles that constituted the protests, OGA argued that fares and issues related to public transportation were nothing but a trigger for the expression of accumulated indignation against the political system. They attempted to promote frame transformation, challenging the interpretation of the ongoing struggle around transportation, and pushing a nationalist frame according to which what was going on was a defense of the country.

\title{
V.2. The Case of Turkish Protests: Protection of the park vs democratic rights
}

${ }^{7}$ Taksim Solidarity defines itself as "a coalition of 124 trade unions, political parties, community groups, sport club fan groups and initiatives embracing differences and diversity, and expressing demands through peaceful and democratic means." The Coalition calls for "healthy urbanization and liveable city" and presents itself as the voice of those who cry for "greener, more liveable, humane and
The posts on two selected Facebook pages, Taksim Solidarity (TS) ${ }^{7}$ and Prime Minister Recep Tayyip Erdogan (RTE), present examples of the symbolic struggles that took place during the first 30 days of the Gezi Park protests in 2013. At the background of these struggles stand the question over the legitimacy of the protests underpinned by contested understandings of democracy. The posts on the RTE page emphasize electoral democracy as the only legitimate way of collective decision-making and seek to de-legitimatize the political power of the protests. The posts on the TS page, in contrast, portray protesting as a democratic right of individuals, especially in a political regime becoming increasingly authoritarian. These different understandings of the legitimacy of protests as a political activity stand at the background of further contestations over the causes of the protests. 
democratic city and country" (Taksim Dayanisma 2013).
Before we move on to the combined analysis of the Facebook posts, it is important to note some of the differences between the posts on the Facebook pages of TS and RTE. These posts do not only differ in numerical terms (the number of posts on TS's page is significantly higher than RTE's in the same period), there are also important qualitative differences. While TS started posting content related to the protests from the very first day of protests (May 28), the first protest related post on RTE's page appeared on the sixth day of protests (June 2). Between May 28 to June 2, the posts on the RTE page actively ignored the protests and sought to establish a different "reality" about the political situation in the country.

In the first 5 days, RTE's Facebook page included news about the achievements of the governing Justice and Development Party (JDP) focusing "successful" infrastructure projects. The first protest related post appeared in June. This post portrayed the protests as futile efforts of a small number of marginal groups who had lost at the ballot box. It read:

"These are the efforts of those who could not win at the ballot box. Our prime Minister defined Taksim Gezi Park protests as the extremist activity of the marginal groups... He said "They should know that we will all go to ballot box in ten months time. The people will give the required response through the ballot box... This is a solidarity of extremist marginal groups supported by the opposition party, People's Republic Party” (June 2, 2013, RTE's Facebook page).

The post illustrates the dominant government narrative about the Gezi Park protests. It frames the protests as an anti-democratic movement of "extremist groups" taking place against the will of the majority. This and similar posts on the RTE's page sought to mobilize supporters for pro-government counter rallies, "Respect for the National Will", which took place in various major cities two weeks after Gezi protests started.

TS's page, in contrast, sought to mobilize the protesters and framed protesting as a democratic right of citizens, e.g., against police violence, the authoritarian regime of the JDP Government or illegal construction works in public spaces. Besides bringing the symbolic struggles over the causes of the protests to the fore, the TS Facebook page also served as a platform to disseminate practical information on a wide variety of issues ranging from first aid against tear gas to legal advice for those who were arrested during the protests. Especially with the increase of police violence, TS page became a key site of information on a variety of topics to assist protestors.

When we leave out the posts that are not about the protests or do not touch the causes of the protests, the combined analysis of the posts from both pages, from May 28 to June 27, reveals eight key reasons for the protests, as shown in Chart 5.

What is noteworthy, in light of the interpretation of protests as "events", is how these reasons evolved, lost or gained traction over time. Chart 6 lays out the frequency of different causes for protests as mentioned in both Facebook pages.

The two reasons mentioned on RTE's page, "conspiracy against the government" and the "electoral failure of the opposition" do pop up, yet in an eclectic rather than a continuous manner. They seem to be published to validate the dominant government narrative at the time. Overall, the pro-government discourse sought to delegitimize the protests either by presenting them as actions and demands of a few marginalized individuals, or by situating them away from "ballot box" results and electoral democracy more generally.

As noted, the majority of the posts that bring the causes of the protests to the fore steams from TS's Facebook page. The most frequently articulated reason for the protests was "solidarity with those who protest". These posts empha- 
Chart 5 - Frequency of issues on TS and RTE Facebook pages between 28 May and 26 June 2013

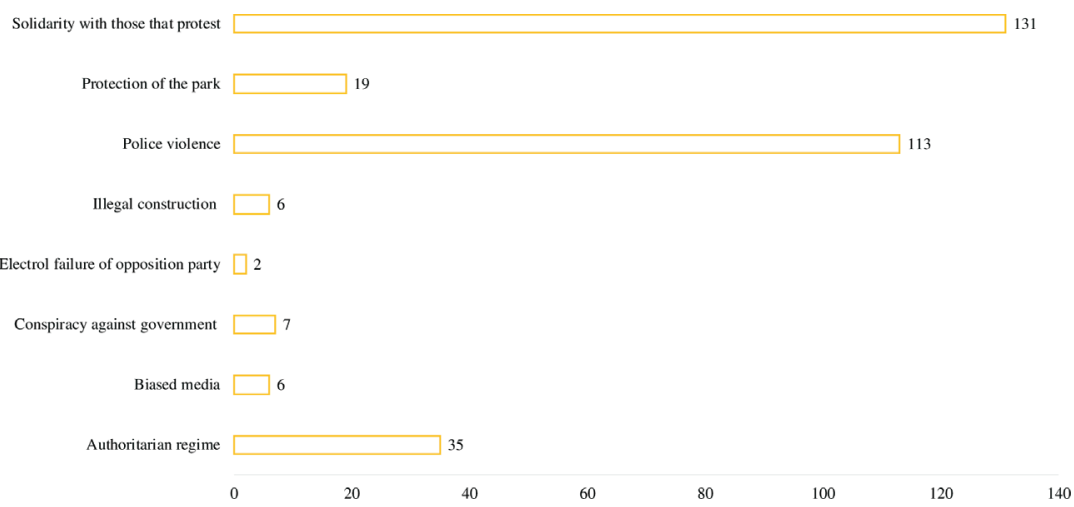

Source: Protests and Political Engagement Research Project.

Chart 6 - Frequency of issues mentioned in TS and RTE Facebook pages between 28 May and 26 June 2013

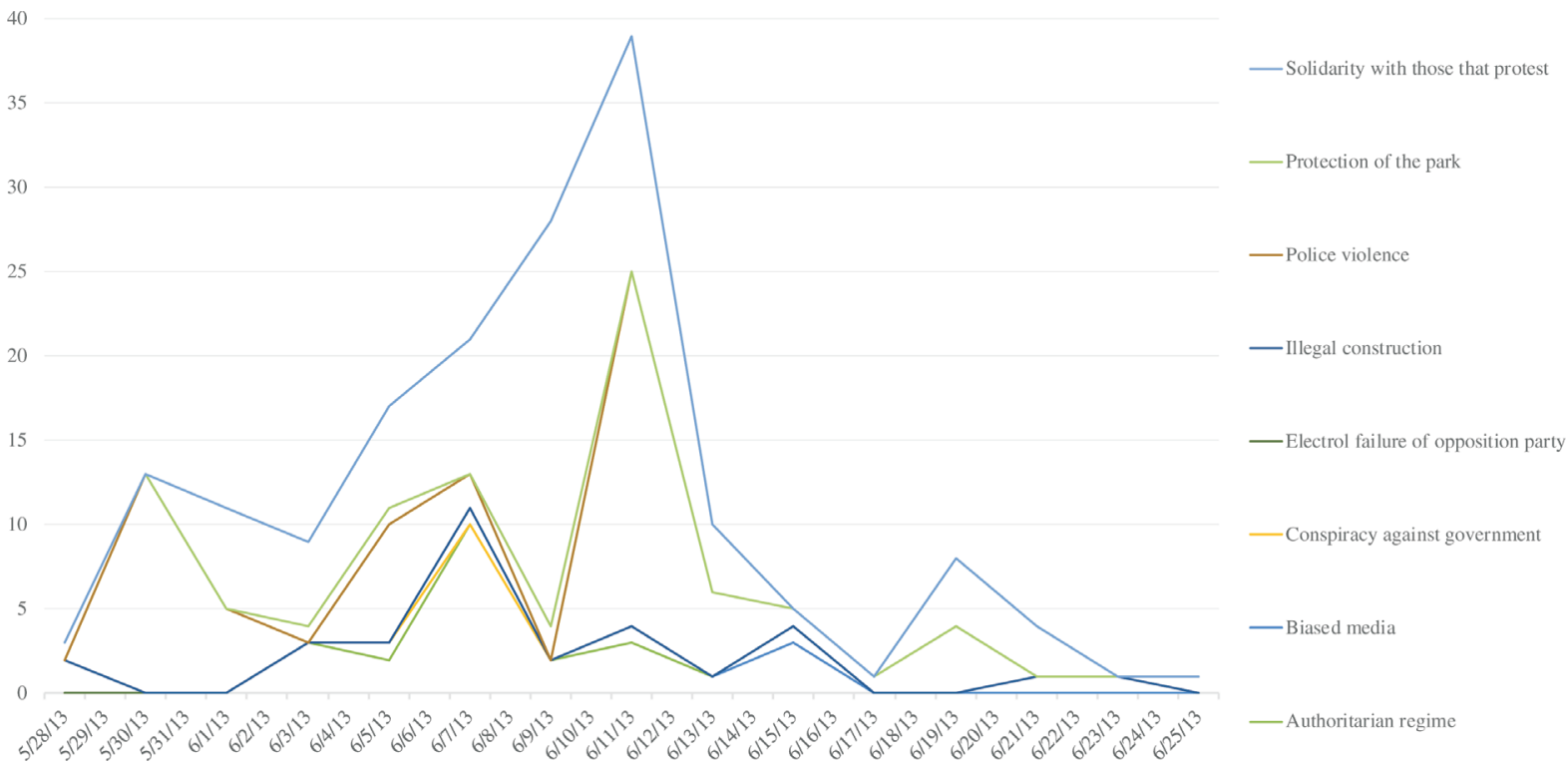

Source: Protests and Political Engagement Research Project.

sized the need to show solidarity with the ones protesting on the ground, coming from various places both within Turkey and from abroad. The second widespread reason for the protests concerned the police violence against (peaceful) protesters. The third frequently mentioned cause was the authoritarian regime of the governing Justice and Development Party (JDP). The existing literature notes the increasing state oppression and authoritarian style of the government as significant reasons for the emergence and the proliferation of the Gezi Park protests (Abbas 2013; Gole 2013).

Having said that, it is difficult to disentangle these three prevalent issues from each other. Police violence is and can be seen as a clear manifestation of an authoritarian regime. These two causes, in return, obviously feed into the need to show solidarity to those who suffer under police violence and an authoritarian regime. 
${ }^{8}$ Konda Research and Consultancy's survey (2014) involving 4411 participants between July 6-7, 2013, similarly suggests that $73 \%$ of the protestors who identified themselves as "ordinary citizens" decided to actively get involved in the protests after police violence.
As the Chart 7 shows, May the $30^{\text {th }}$ was a turning point in Gezi Park protests. ${ }^{8}$ The number of posts emphasizing police violence increased drastically. This went hand to hand with the rise of posts expressing solidarity to protesters. The police intervention to the park with tear gas and water cannons and the destruction of protest tents on that day transformed protests from being a smallscale environmental protest into one of the biggest nation-wide movements in the history of the Turkish Republic. The initial reason of the protests, the removal of a handful of trees at Gezi Park to build a shopping mall, was dismissed as the cause of the subsequent upheaval. Instead, protesters began to emphasize the increasingly authoritarian policies of the government (Benhabib 2013). A post on June 6, for example, reads that "Three uprooted trees in Taksim Gezi Park turned into a struggle of democratic rights in all over Turkey". A call for the "right to the city" turned into a call for the "right to live in a truly democratic country" (Taksim Solidarity's page, June 6, 2013). Similarly, the press release published on this page on June 2 establishes the legitimacy of the Gezi Park movement by referring to PM Recep Tayyip Erdogan's anti-democratic policies of restrictions on freedom of speech and the State's interventions in individual life styles. In this press release, protesting is presented as a legitimate right of citizens against the state "which tries to instill a fear atmosphere in order to transform the whole society into a large prison through suppression, violence and force" (June 2, 2013). Tayyip Erdogan, who was the Prime Minister then, declined the use of force, claimed that he personally gave the order, and that he was proud of the police force's work during the protests (Radikal 2013).

The uncompromising tone of Erdogan fueled the tensions but at the same time it had an important transformative effect. Arguably, it brought together different groups which were traditionally antagonistic to each other. These groups created a deliberative space that contested the notion of "the other" historically constructed in Turkey, politically, economically, and socially (Mendonça \& Ercan 2015). Protests included a variety of groups such as trade unions, environmentalist, Lesbian, Gay, Bisexual and Transgender (LGBT) groups, feminist groups and "anti-capitalist Muslims". A progressive dialogue with the

Chart 7 - Distribution of three prevalent issues mentioned in TS and RTE Facebook pages between 28 May and 26 June 2013

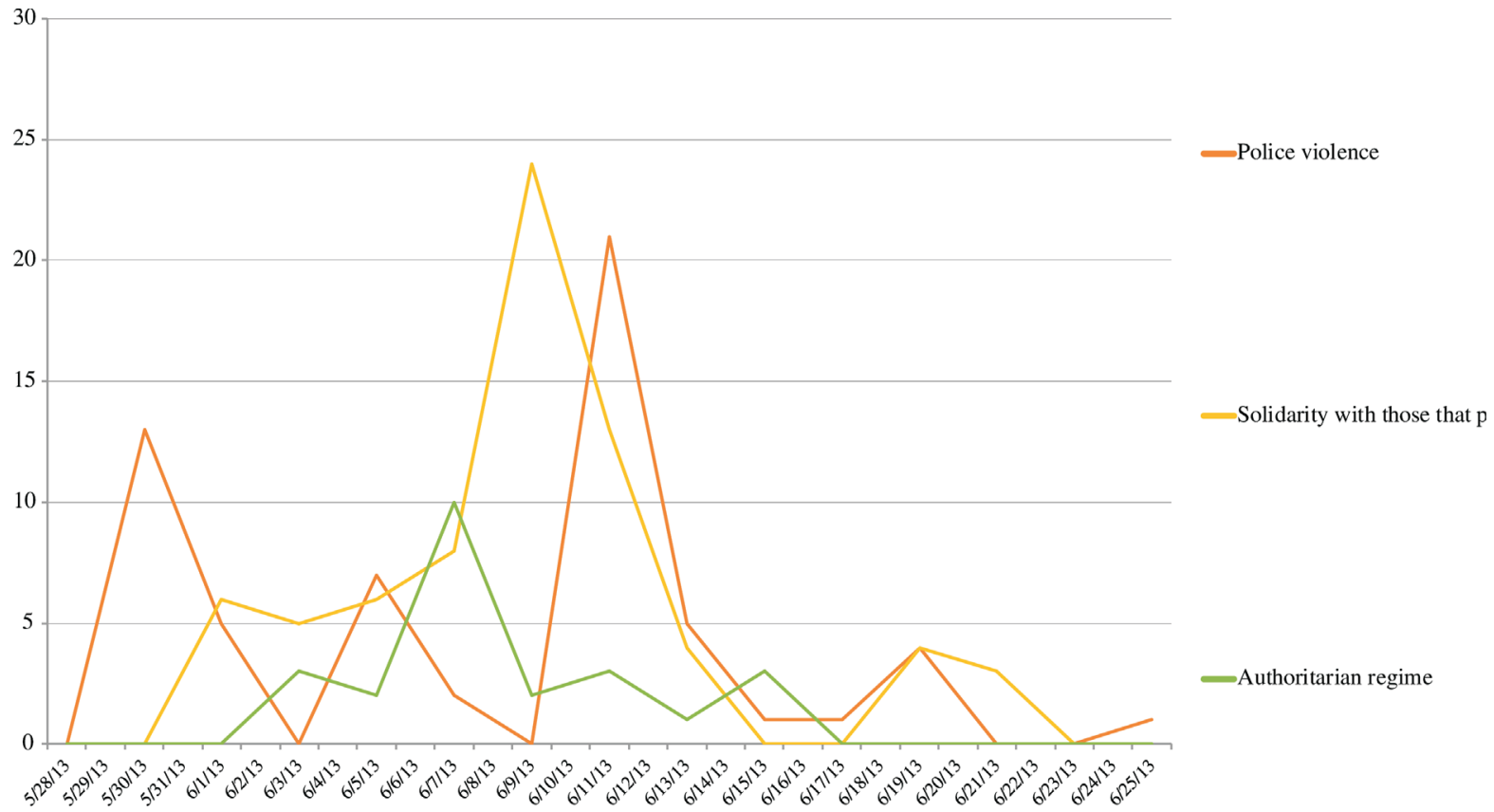

Source: Protests and Political Engagement Research Project. 
Kurdish minority was also evident during the protests. Such dialogues contributed to the construction of Gezi Park protests as a pluralistic movement that went beyond the interests of Istanbul's middle class.

The pictures that circulated on TS's page brought this diversity into focus. For example, Figure 5 shows two men, one holding a Turkish flag and the other the flag of the Peace and Democracy Party, which represented the Kurdish minority between 2008 and 2014. This image signifies the symbolic solidarity between nationalist and Kurdish forces during the protests against state violence and reads as "an exceptional moment of resistance in Taksim". This solidarity, however, should not be read as finding a common language between Turks and Kurds. But it suggests to remember the violent past and forgotten injustices in order to alter the present relations between majority and minority groups. As such, this act of solidarity offers an illuminating example of protests as events. The disruption caused by the protests created a space for reflection and interpretation about the past and future of the Turkish-Kurdish conflict, which constitutes one of the most pressing political issues in Turkey.

Similarly, the protests also brought a fresh perspective on the way the relationship between secular and Islamic groups are conceived by each other. Figure 6 shows, for instance, the Friday prayers taking place at the Taksim Square in support of the protests.

These images did not simply represent the "real world" of the Gezi Park, they also played a meaning-making role by contesting established dichotomies between secularism/religion and Turkishness/Kurdishness. They opened new possibilities of co-existence among traditionally conflicting groups. Such images helped to imagine and reinforce the possibilities of solidarity across deep divisions. Furthermore, during the course of events, these images made the police violence visible and emphasized the non-violent character of the protests. Such tactics of making state repression visible worked against the PM Erdogan's posts that constructed the protests as a violent attempt of a few "marginals".

The emphasis on "life" against "death" and "destruction" produced by the police is also evident in many posts. For example, a post published on TS page, on June 4, made it explicit that "Our resistance is peaceful, not destructive". The discursive framing of protests as "non-violent peaceful resistance" was also sustained through posting photos of workshops organized for children and of a

Figure 5 - 'An exceptional moment of resistance in Taksim’ 12 June 2015

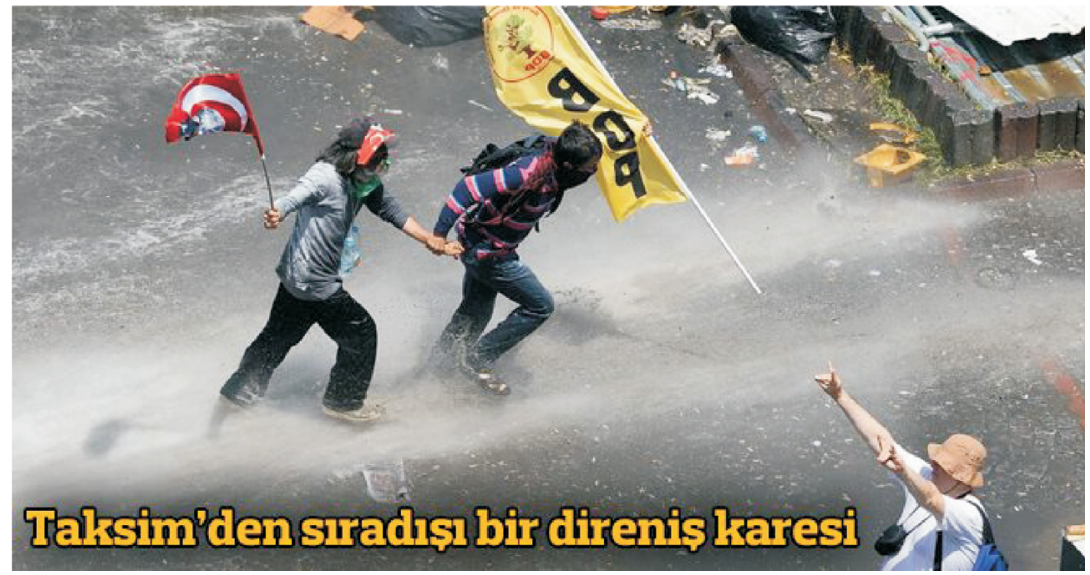

Source: Image posted on TS Facebook page (12 June 2013). 
Figure 6 - Co-existence of diverge beliefs, 7 June 2013

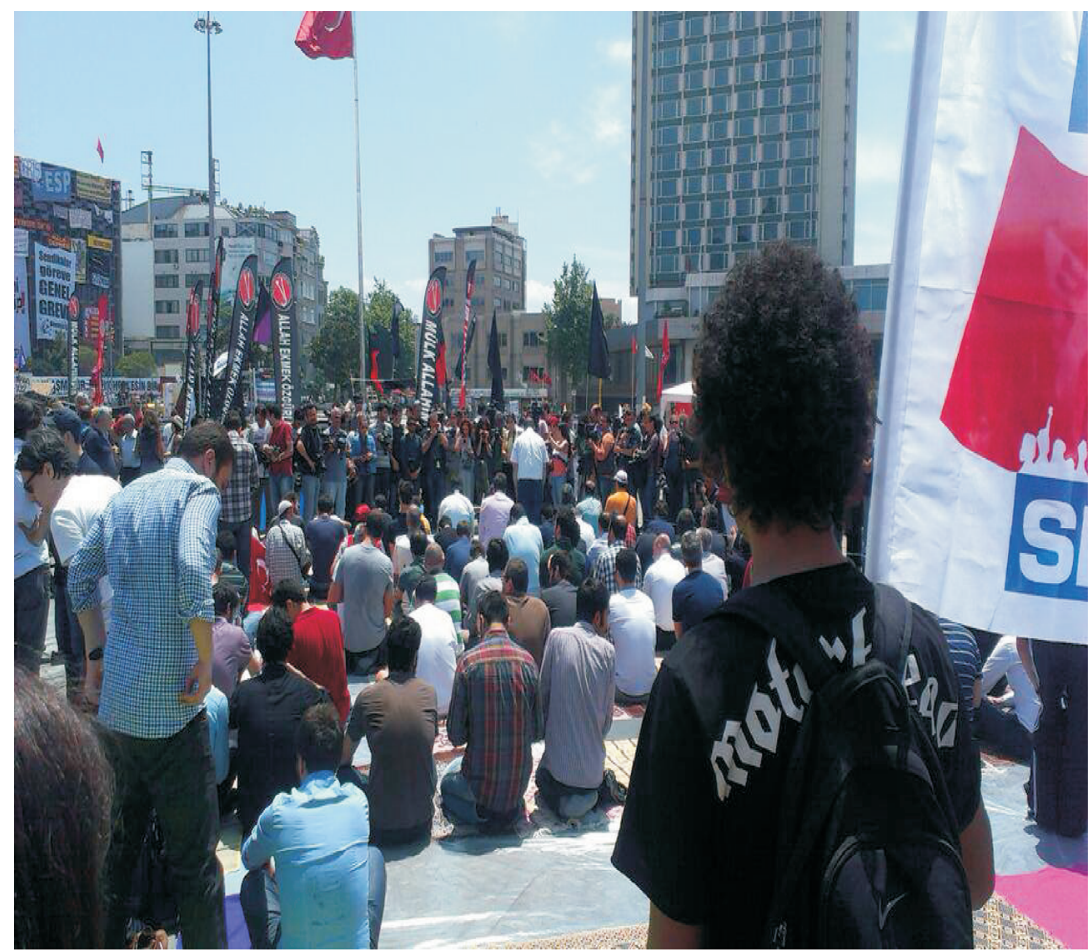

Source: Image posted on TS Facebook page (7 June 2013).

library at the park (Figure 7, Figure 8). In its press release published on June 11, Taksim Solidarity stated:

"For two weeks women, youth, gays and lesbians, socialists, and those who believe and who do not have been calling for their democratic rights in seventy-seven cities through poems, songs, slogans, and dance. The government, however, not only refuses to hear these demands, it also threatens its own citizens and organizes pro-government protests, and in doing so, the government fuels polarization in the society".

Such portrayal of peaceful and non-violent character of the protests against the violent character of police intervention helped to establish not only the legitimacy of the protests, but also brought the shifting causes of the protests to the fore.

\section{Discussion}

Having shown the symbolic struggles around the "causes" of the protests, we now return to our original assumptions and explain why the concept of event is important to comprehend these movements. The concept proves to be helpful in at least three important ways. First, it enables us to conceive the symbolic struggles as a central element of the processes. Events are not "already there": they are built through collective meaning-making processes and discursive struggles. Second, the concept sheds light on the tangible consequences of these struggles. The way the process is framed has actual consequences for the continuity of the event itself. Different interpretations of the past and the present open and close diverse possibilities for the future. Third, the concept of events suggests avoiding a sterile (and very frequent) question pervading the literature on protest movements: when have they actually started? The concept helps to show that the past of a protest movement is continuously reconstructed along 
Figure 7 - 'Children's Workshop: Not the voice of violence, but the voice of peace is rising at Gezi'

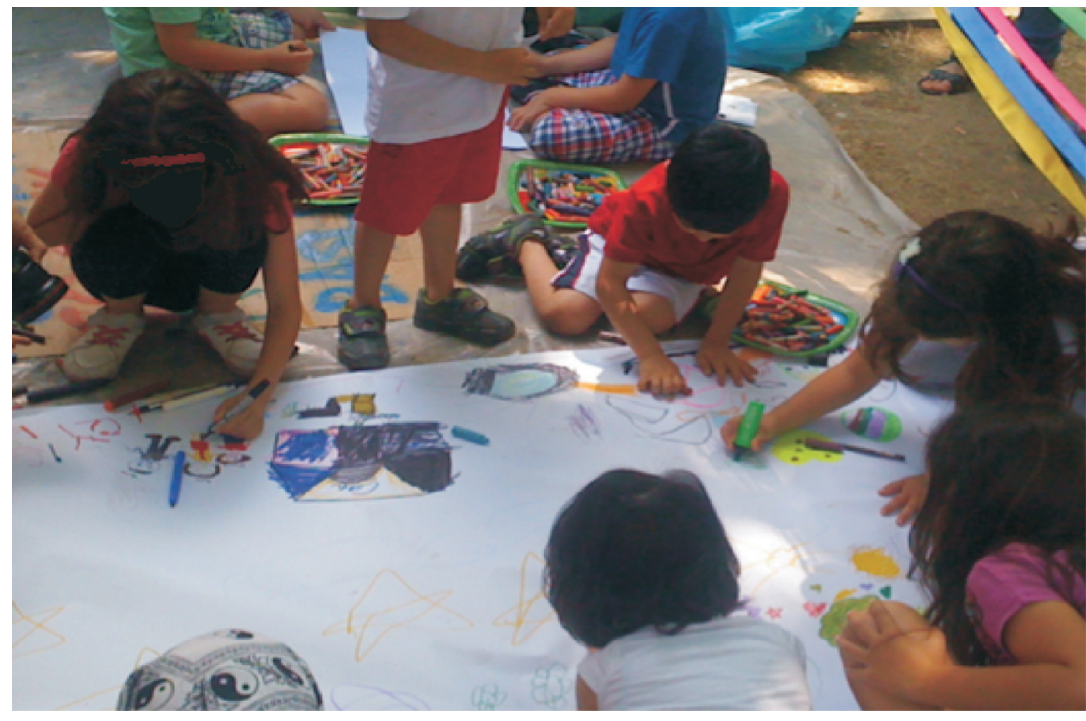

Source: Image posted on TS Facebook page (10 June 2013).

Figure 8 - Gezi Library

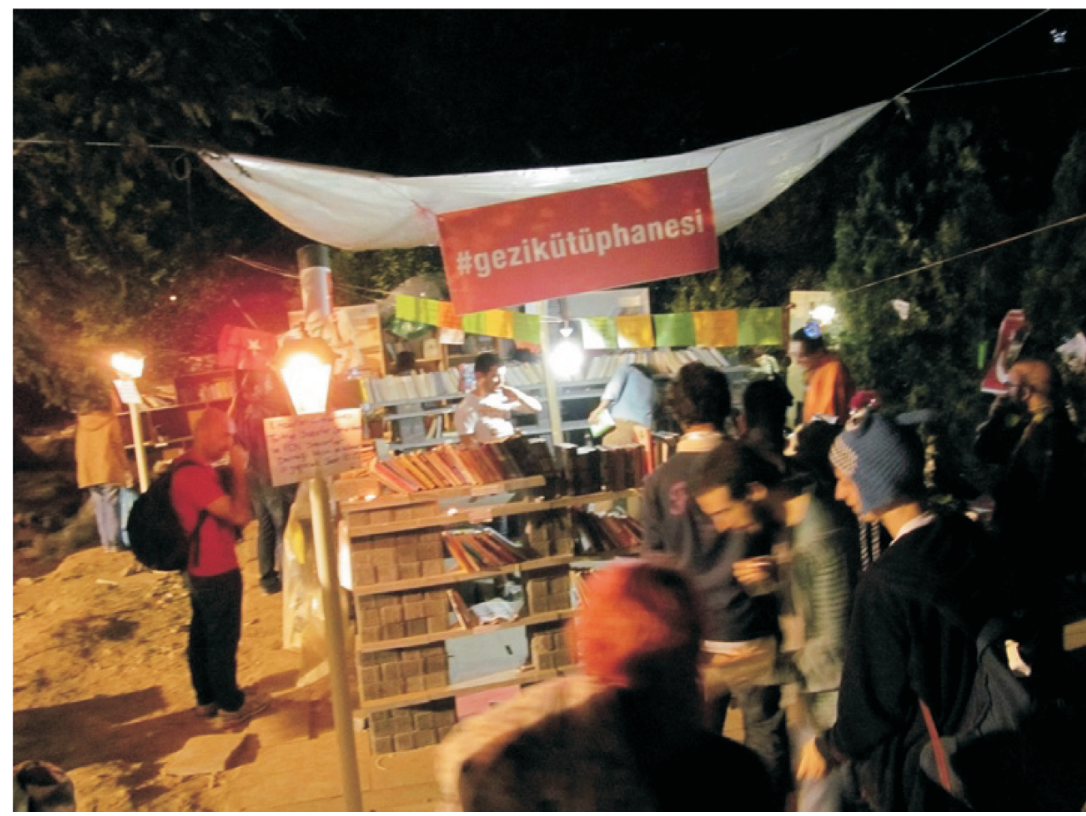

Source: Image posted on TS Facebook page (7 June 2013).

the struggle. Different interpretations of the protests" causes or origins are themselves part of the political dimension of these processes. With different interpretations, the event keeps taking different directions and transforms itself.

In both Brazil and Turkey, protests entailed intense symbolic struggles over what was going on. Different groups established different origins and causes for the protests and their interpretations yielded different consequences in terms of future possibilities. In Brazil, the Free Fare Movement (MPL) presented a focused struggle over the right to the city. By emphasizing the main cause of the 
protests in terms of an issue of transportation, they resisted the diversification of the agenda and the possible political uses of such diversification. This did not mean that MPL had a limited claim. The group also presented a wider perspective through the turnstile metaphor, which worked as a bridging frame. In contrast to MPL, The Giant Awoke (OGA) presented a pulverized agenda mainly targeting politicians, the political system and the lack of rights in the country. It sought to promote a frame transformation process, arguing that the causes to demonstrate were rather different (and broader) than the claims raised by MPL. By linking the protests to a crisis of representation, they opened possibilities for the de-legitimation of the Federal Government and the Workers' Party (PT). Although MPL did not support PT, it did not support the right-wing adversaries of PT either. In these symbolic struggles, each interpretation of the protests" causes implied diverse horizons of possible futures.

This interpretive contention was a struggle that had consequences in terms of who was at the streets and what would result from this. MPL, at one point, decided to leave the streets. $O G A$ accused it of having sold itself and of giving up a struggle for a just country. MPL presented its conception of justice through the idea of the right to the city, bridging its struggles with many claims mobilized by other actors. $O G A$ sought a frame transformation, proposing an anti-politics view in order to explain the lack of rights. The symbolic struggles over the event disclosed a dispute over the streets and over the future of the country.

As events cannot be entirely circumscribed spatially and temporally, it is possible to trace some of the developments of these symbolic struggles in the years following 2013. The year of 2014 was marked by an enormous political polarization, expressed in the presidential elections. Despite the re-election of president Dilma Rousseff (PT), her legitimacy was deeply challenged by several actors. She won with $51,64 \%$ of the votes, against $48,36 \%$ of her challenger. The North and the Northeast of the country (poorer areas) mostly voted for Rousseff, while the South and the Southeast (richer areas) voted for Aécio Neves (PSDB). In 2015, the deepening of corruption investigations led to new massive protests on the streets, most of them in the nationalist anti-politics tone adopted by OGA. Some demonstrators claimed for a military intervention, suggesting that democracy, broadly defined, was not capable to solve the country's problems. This year was characterized by overwhelming political instability and economic crisis. In 2015, the National Congress started to evaluate a request for the impeachment of President Rousseff and approved her removal from the office on 31 August 2016. This development shows that the frame transformation advanced in $O G A$ posts (and in many other arenas by several social actors) succeeded in molding the consequences of the event.

In Turkey, those initiating and organizing the protests were the ones attempting to enlarge the interpretive frames defining the causes of the events. They sought to show that their struggle was not only an environmental claim against a shopping center, but a broader fight against the authoritarianism of then Prime Minister Erdogan. They deliberately sought a frame extension, capable to expand the boundaries of the struggle to encompass different views and involve diverse groups. Against the acts of frame extension, Erdogan's supporters sought to restrict the scope of the struggle by framing the protests as illegitimate political action carried out by a handful of extremists. They sought to depoliticize the causes of the protests by keeping the discussion focused on the construction of a shopping mall or by denying to engage with the reasons put forward by pro-protest groups such as Taksim Solidarity.

As such, symbolic struggles in Facebook posts were not simply a struggle over the meaning of the Gezi protests. What they revealed was the broader and deeper disputes over the meaning of democracy in Turkey. The event of Gezi 
Park did not resolve the disputes over how democracy worked, but created various forms of displacement over its meanings. The inclusive language of the Gezi protests helped to challenge the provocative and patriarchal tone of Turkish politics (Varol 2014). The protests opened up new possibilities for democratic involvement, especially concerning the neighborhood councils organized around city parks (Mert 2016, p.13).

The Gezi Park protests certainly did not create a shift in the government's treatment of minorities and oppressed voices. In fact, since then the government has significantly increased its surveillance powers over these voices and continued to suppress any small-scale protest movement. However, the Gezi protests created a diverse range of awareness within the public sphere. In the words of anthropologist and journalist Ayse Cavdar, a key achievement of the Gezi protests was "to shatter the narrow identities imposed by state discourse". Gezi brought together a diverse range of identities; conservative Muslims and secularists, nationalist Turks and Kurds, Kurds, Alevis and Sunnis. Gezi Protests were a response to the longstanding political silencing and oppression of different sections of Turkish society, and therefore it cannot be reduced to another secular Kemalist movement. The inclusive nature of the protests triggered new discourses in Turkish social and political life. Perhaps the rise of pro-Kurdish People's Democratic Party (PDP) in recent years and its increased popularity not only among Kurdish citizens, but Turkey's other minority groups, can be seen as one of the long-term effects of Gezi. In 2015 general elections, PDP managed to surpass the draconian $10 \%$ threshold in Turkish election system and gained 88 seats in the Parliament. This success was also the outcome of the party's deliberative shift in its discourse from only promoting Kurdish rights towards incorporating rights of all minority groups that had been traditionally oppressed in Turkish social and political life (see for example, Bozcali \& Cagri 2013; Unan 2015)

The question here is not so much whether such "awakenings", occurred during and after the Gezi protests, have led to great transformations, "ruptures", in Turkish politics. The question is what forms of "cracks" the Gezi protests created in the social and political fields. In this regard, we also need to resist romanticizing the Gezi experience and recognize its limitations in the areas of political inclusion/exclusion and in the public recognition of the past experiences of dispossession in Turkey (Parla \& Ozgul 2016). Seen in these terms, we also argue that the Gezi Park protests did not lead to any "tangible cracks" in Turkish politics, but showed the potential of transformative politics that could turn themselves into "ruptures". Therefore, it is important to see the Gezi protests not simply as a symbol of the new form of inclusive political activism in Turkey, but as an ongoing event: a symbolic struggle over the meaning of the event itself, the impact of which continues today.

In the case of 2013 protests, the symbolic struggles over the events were essentially a field for broader political battles, in which different reinterpretations of the past is connected with diverse possibilities for the future. This points out to the interpretive power of events, which lies in their capacity to open a chasm, showing the contingency of a society that can never be fully sutured. By re-opening the past, the rupture re-opens the future in very practical ways. Our study shows how such symbolic struggles can follow different paths in different countries. While in Brazil the frame extension has put democracy in jeopardy, in Turkey, it was essential to challenge authoritarianism and foster democratic ideals.

IRicardo Fabrino Mendonça (ricardofabrino@ hotmail.com) has a PhD in Communication Studies from UFMG and works currently as Associate Professor in the Political Science Department at UFMG. He holds a CNPq fellowship and a PPM/Fapemig fellowship. Institutional affiliation: Department of Political Science, UFMG, Belo Horizonte, MG, Brazil. 
IISelen Ercan (selen.ercan@canberra.edu.au) has a PhD in Political Science from Australian National University and works currently as an Associate Professor of Politics at the University of Canberra. Institutional affiliation: Centre for Deliberative Democracy and Global Governance, University of Canberra, Canberra, Australian Capital Territory, Australia.

IIIUmut Ozguc (u.ozguc@unsw.edu.au) has a PhD in International Politics and is currently a post-doctoral research fellow at UNSW, Canberra. Institutional affiliation: School of Humanities and Social Sciences, University of New South Wales (UNSW), Canberra, Australian Capital Territory, Australia.

${ }^{\text {Iv }}$ Stephanie Reis (slgreis92@gmail.com) is a social scientist and has worked as a research assistant at Margem - Research Group on Justice and Democracy. Institutional affiliation: Margem - Research Group on Justice and Democracy, UFMG, Belo Horizonte, MG, Brazil.

vPaula Guimarães Simões (paulaguimaraessimoes@yahoo.com.br) has a PhD in Social Communication at Federal University of Minas Gerais and works as Assistant Professor at the same institution. Institutional affiliation: Department of Social Communication, Federal University of Minas Gerais, Belo Horizonte, MG, Brazil.

\section{References}

Abbas, T., 2013. Political Culture and National Identity in Conceptualising the Gezi Park Movement. Insight Turkey, 15(4), pp.19-27. DOI: $10.1057 / 9781137469021.0008$

Accornero, G. \& Pinto, P.R., 2015. Mild Mannered? Protest and mobilisation in Portugal under austerity, 2010-2013. West European Politics, 38(3), pp.491-515. DOI: 10.1080/01402382.2014.937587

Araújo, R.P.A.; Penteado, C.L.C. \& Santos, M.B.P., 2015. Democracia digital e experiências de e-participação. História, Ciências, Saúde - Manguinhos, 22, pp.1597-1619.

Arendt, H., 1993. A dignidade da política. Ensaios e conferências. Rio de Janeiro: Relume-Dumará.

Badiou A., 1994. Para uma nova teoria do sujeito. Rio de Janeiro: Relume-Dumará.

Barría, F.S., 2018. La política de la protesta en regímenes autoritarios: síntesis crítica. Revista de Sociologia e Política, 26(65), pp.132-154. DOI: 10.1590/1678-987317266506

Benford, R.D. \& Snow, D.A., 2000. Framing Processes and Social Movements: An Overview and Assessment. Annual Review of Sociology, 26(1), pp.611-639. DOI: 10.1146/annurev.soc.26.1.611

Bennett, W.L. \& Segerberg, A., 2013. The Logic of Connective Action. New York: Cambridge University Press.

Bozcali, F. \& Cagri, Y., 2013. A Look at Gezi Park from Turkey's Kurdistan. Cultural Anthropology. Retrieved from https://culanth.org/fieldsights/396-a-look-atgezi-park-from-turkey-s-kurdistan. Accessed on Apr. $24^{\text {th }}$.

Bringel, B., 2017. Crisis política y polarización en Brasil: de las protestas de, 2013 al golpe de, 2016. In B. Bringel \& G. Pleyers, eds. Protesta e indignación global: los movimientos sociales en el nuevo orden mundial. Buenos Aires: CLACSO.

Bringel, B \& Pleyers, G., 2015. Junho de 2013? dois anos depois: polarização, impactos e reconfiguração do ativismo no Brasil. Nueva Sociedad, v. 259, p. 4-17.

Castells, M., 2012. Networks of Outrage and Hope: Social Movements in the Internet Age. Cambridge: Polity Press.

Cefaï, D., 2007. Porquoi se mobilise-t-on? Les théories de l'action collective. Paris: La Découverte.

Cefaï, D., 2017. Públicos, Problemas Públicos, Arenas Públicas: O que nos ensina o pragmatismo. Novos Estudos, 36(1), pp.187-213. DOI: 10.25091/s0101-3300201700020007

Charaudeau, P., 1997. Le discours d'information médiatique - La construction du miroir social. Paris: Nathan.

Chong, D. \& Druckman, J. N., 2007. Framing Theory. Annual Review of Political Science, 10 (1): 103-126. DOI: 10.1146/annurev.polisci.10.072805.103054

D’Andréa, C. \& Ziller, J., 2014. Imagens violentas nas manifestações de, 2013: multiplicidades, estética e dissenso nas narrativas em vídeo de comuns e de instituições. In R.H.A. Silva, ed. Ruas e redes: dinâmicas dos protestosBR. Belo Horizonte: ED. Autêntica.

Dayan, D., \& Katz, E., 1994. Media Events: The live broadcasting of history. Cambridge, MA: Harvard University Press.

Deleuze, G., 1975. Lógica do sentido. São Paulo: Perspectiva.

Deleuze, G., \& Guattari, F., 1994. What is Philosophy? New York: Columbia University Press.

Della Porta, D., 2008. Eventful Protest, Global Conflicts. Distinktion, 9(2), pp.27-56. DOI: 10.1080/1600910x.2008.9672963

Della Porta, D., 2013. Can democracy be saved? Cambridge, MA: Polity Press.

Della Porta, D., 2015. Social Movements in Times of Austerity: Bringing Capitalism Back into Protest Analysis. Cambridge: Polity Press.

Della Porta, D., ed., 2017. Global Diffusion of Protest. Riding the protest wave in the neoliberal crisis. Chicago: University of Chicago Press.

Demirhan, K., 2014. Social Media Effects on the Gezi Park Movement in Turkey: Politics under Hashtags. In B. Patrut \& M. Patrut, eds. Social Media in Politics: Case Studies on the Political Power of Social Media. Cham: Springer Publications.

Dewey, J., 1993. Logique. Théorie de l'enquête. Paris: PUF.

Dewey, J., 1954. The Public and Its Problems. Chicago: Swallow Press.

Entman, R.M., 1993. Framing: Toward clarification of a fractured paradigm. Journal of Communication, 43(4), pp.51-58. DOI: 10.1111/j.1460-2466.1993.tb01304.x 
Farro, A.L. \& Demirhisar, D.G., 2014. The Gezi Park Movement: A Turkish experience of the twenty-first century collective movements. International Review of Sociology, 24(1), pp.176-189. DOI: 10.1080/03906701.2014.894338

Foucault, M., 2007. A ordem do discurso. São Paulo: Edições Loyola.

França, V.V. \& Bernardes, M., 2016. Imagens, crenças e verdade nas manifestações de 2013 e 2015. Rumores, 10(19), pp.8-24. DOI: 10.11606/issn.1982-677x.rum.2016.112718

Gamson, W., 1992. Talking Politics. Cambridge: Cambridge University Press.

Gamson, W. \& Modigliani, A., 1989. Media discourse and public opinion on nuclear power: a constructionist approach. American Journal of Sociology, 95 (1): 1-37. DOI: 10.1086/229213

Gitlin, T., 1980. The whole world is watching: mass media in the making and unmaking of the new left. Berkeley/Los Angeles/Londres: University of California Press.

Goffman, E., 1986. Frame analysis: an essay on the organization of experience. Boston, Northeastern University Press

Goffman, E., 1974. Frame Analysis: An essay on the organization of experience. New York: Harper and Row.

Gohn, M.G., 2014. A Sociedade Brasileira em Movimento: vozes das ruas e seus ecos políticos e sociais. Caderno CRH, 27(71), pp.431-441. DOI: 10.1590/s0103-49792014000200013

Gole, N., 2013. Gezi - Anatomy of a Public Square Movement. Insight Turkey, 15(3), pp.7-14.

Gomes, W., 2016. "Nós somos a rede social”. In R.F. Mendonça; M.A. Pereira \& F. Filgueiras, eds. Democracia Digital. Belo Horizonte: Ed. Autêntica.

Goodwin, J. \& Jasper, J., 2004. Rethinking Social Movements: Structure, meaning and emotion. New York: Rowman \& Littlefield.

Guner, E., 2016. The Impact of Social Media on Political Change: Gezi protests in Turkey. In Annual Meeting of the Southern Political Science Association. New Orleans.

Harlow, S. \& Harp, D., 2012. Collective Action on the Web. Information, Communication and Society, 15(2), pp.196-216. DOI: 10.1080/1369118x.2011.591411

Joas, H., 1997. G. H. Mead: A contemporary re-examination of his thought. Cambridge, MA: The MIT Press.

Judensnaider, E.; Lima, L.; Pomar, M. \& Ortellado, P., 2013. Vinte Centavos: a luta contra o aumento. São Paulo: Veneta.

Juris, J., 2012. Reflections on \#Occupy Everywhere: Social media, public space, and emerging logics of aggregation. American Ethnologist, 39(2), pp.259-279. DOI: 10.1163/9789004324589_021

La Rosa, A., 2014. Social Media and Social Movements around the World: Lessons and Theoretical Approaches. In B. Patrut \& M. Patrut, eds. Social Media in Politics: Case studies on the political power of social media. Cham: Springer.

Malini, F.; Goveia, F.; Ciarelli, P. \& Carreira, L., 2016. A viralização da revolta em redes sociais: genealogias de \#Vemprarua. In R.F. Mendonça; M.A. Pereira \& F. Filgueiras, eds. Democracia Digital: publicidade, instituições e confronto político. Belo Horizonte: Ed. Autêntica.

Maricato, E., 2013. É a Questão Urbana, Estúpido! In E. Maricato et al. Cidades rebeldes: passe livre e as manifestações que tomaram as ruas do Brasil. São Paulo: Boitempo.

McAdam, D., 1996. The framing function of movement tactics: strategic dramaturgy in the American civil rights movement, In D. McAdam, J. D. McCarthy e M. N. Zald, eds. Comparative perspectives on social movements: political opportunities, mobilizing structures and cultural framings. Cambridge: Cambridge University Press.

McAdam, D. \& Sewell, W., 2001. It's About Time: Temporality in the study of social movements and revolutions. In R.R Aminzade et al. Silence and Voice in the Study of Contentious Politics. Cambridge: Cambridge University Press.

Mead, G.H., 1932. The Philosophy of the Present. LaSalle, IL: Open Court.

Mendonça, R.F. \& Ercan, S.A., 2015. Protest and Deliberation: Strange Bedfellows? Revealing the Deliberative Potential of 2013 Protests in Turkey and Brazil. Policy Studies, 36(3), pp.267-282.

Mendonça, R.F., 2007. Movimentos sociais como acontecimentos: linguagem e espaço público. Lua Nova, 72, pp.115-142. DOI: $10.1590 / \mathrm{s} 0102-64452007000300005$

Mendonça, R.F., 2017. Singularidade e identidade nas manifestações de 2013. Revista do Instituto de Estudos Brasileiros, 66, pp.130-159. DOI: 10.11606/issn.2316-901x.v0i66p130-159

Mendonça, R.F. \& Simões, P.G., 2012. Framing: Different analytic approaches to a concept. Revista Brasileira de Ciências Sociais, 27(79), pp.187-201. DOI?

Mercea, D.; Karatas, D. \& Bastos, M., 2017. Persistent Activist Communication in Occupy Gezi. Sociology, 52(5), pp.915-933. DOI: $10.1177 / 0038038517695061$

Mert, A., 2016. The Trees in Gezi Park: Environmental policy as the focus of democratic protests. Journal of Environmental Policy \& Planning. DOI: 10.1080/1523908X.2016.1202106

Milan, S., 2015. From Social Movements to Cloud Protesting: The evolution of collective identity. Information, Communication \& Society, 18(8), pp.887-900. DOI: 10.1080/1369118x.2015.1043135

Mouillaud, M., 2002. A crítica do acontecimento ou o fato em questão. In M. Mouillaud \& S.D. Porto, eds. O Jornal: da forma ao sentido, Brasília: Editora UnB.

Nobre, M., 2013. Imobilismo em movimento. São Paulo: Cia das Letras.

Nogueira, M.A., 2013. As ruas e a democracia. Rio de Janeiro: Contraponto.

Nora, P., 1988. O retorno do fato. In J. Le Goff \& P. Nora, eds. História: novos problemas. Rio de Janeiro: Francisco Alves.

Odabas, M. \& Reynolds-Stenson, H., 2017. Tweeting from Gezi Park: Social Media and Repression Backfire. Social Currents, 5(4), pp.1-21. DOI: 10.1177/2329496517734569 
Offe, C., 2013. Participatory Inequality in the Austerity State: A supply-side approach. In A. Schäfer \& W. Streeck, eds. Politics in the Age of Austerity. Cambridge, MA: Polity Press.

Ortiz, I.; Burke, S.; Berrada, M. \& Cortes, H., 2013. World Protests, 2006-2013. New York: Friedrich Ebert Foundation.

Ozturkcan, S.; Kasap, N.; Cevik, M. \& Zaman, T., 2017. An Analysis of the Gezi Park Social Movement Tweets. Aslib Journal of Information Management, 69(4), pp.426-440. DOI: 10.1108/ajim-03-2017-0064

Parla, A. \& Ozgul, C., 2016. Property, Dispossession, and Citizenship in Turkey; or the History of the Gezi Uprising Starts in the Surp Hagop Armenian Cemetery. Public Culture, 28(3), pp.617-653. DOI: 10.1215/08992363-3511574

Papacharissi, Z., 2015. Affective Publics: Sentiment, technology and politics. Oxford: Oxford University Press.

Pennini, A. \& Barrros, E., 2015. Interações e enquadramentos em dias de protesto: dissensos em torno do tema vandalismo. In XXIV Compós. Brasília.

Pereira, M.A. \& Santos, P.P., 2016. Violência coletiva e o Facebook: os protestos de junho de 2013 no Brasil. In R.F. Mendonça; M.A.G. Pereira \& F.B. Filgueiras, eds. Democracia digital. Belo Horizonte: Editora UFMG.

Poell, T., \& Van Dijck, J.F.T.M., 2018. Social Media and New Protest Movements. In J. Burgess; A. Marwick \& T. Poell, eds. The Sage Handbook of Social Media. Los Angeles: SAGE Publications.

Quéré, L., 1995. L'espace public comme forme et comme événement. In I. Joseph, ed. Prendre place. Espace public et culture dramatique. Colloque de Cérizy. Paris: Ed. Recherches.

Quéré, L., 2005. Entre o facto e o sentido: a dualidade do acontecimento. Trajectos, 6, pp.59-75.

Ratto, M. \& Boler, M., 2014. Introduction. In M. Ratto \& M. Boler, eds. DIY Citizenship: Critical Making and Social Media. Cambridge, MA: The MIT Press.

Ricci, R. \& Arley, P., 2014. Nas ruas: a outra política que emergiu em junho de, 2013. Belo Horizonte: Letramento.

Rüdig, W. \& Karyotis, G., 2013. Beyond the Usual Suspects? New Participants in Anti- Austerity Protests in Greece. Mobilization, 18(3), pp.313-330.

Scherer-Warren, I., 2014. Manifestações de rua no Brasil, 2013: encontros e desencontros na política. Caderno CRH, 27(71), pp.417-429. DOI: 10.1590/s0103-49792014000200012

Segurado, R., 2015. A agenda da multidão e o webativismo na cidade de São Paulo. História, Ciências, Saúde - Manguinhos, 22(n. suplementar), pp.1673-1691. DOI: 10.1590/s0104-59702015000500008

Singer, A.V., 2014. Rebellion in Brazil. New Left Review, 85, pp.19-37.

Snow, D.; Rochford Junior, E.B.; Worden, S.K., \& Benford, R., 1986. Frame Alingnment Processes, Micromobilization, and Movement Participation. American Sociological Review, 51(4), pp.464-481. DOI: 10.2307/2095581

Tejerina, B \& Perugorría, I., 2012. Continuities and Discontinuities in Recent Social Mobilizations: From new social movements?to the alter-global mobilizations and the 15M. In B. Tejerina \& I. Perrugoria, eds. From Social do Political: New forms of mobilization and democratization. Bilbao: Universidad del País Vasco.

Theocharis, Y.; Lowe, W.; van Deth, J.W.; Albacete, G.G., 2015. Using Twitter to mobilize protest action: online mobilization patterns and action repertoires in the Occupy Wall Street, Indignados and Aganaktismenoi movement. Information, Communication \& Society, 18(2), pp.202-220. DOI: 10.2139/ssrn.2221824

Tosetto, G.M., 2015. Entre arte e documento: as fotografias da Mídia Ninja e a cultura da convergência. Estúdio, 6(11) pp.31-38.

Tufekci, Z., 2017. Twitter and Tear Gas: The power and fragility of networked protest. New Haven: Yale University Press.

Unan, A.D., 2015. Gezi Protests and the LGBT Rights Movement: A Relation in motion. In A. Yalcintas, ed. Creativity and Humour in Occupy Movements: Intellectual Disobedience in Turkey and Beyond. Basingstoke: Palgrave.

Varol, O., 2014. Revolutionary Humor. Southern California Interdisciplinary Law Journal, 23, pp.555-594.

Warren, A.; Sulaiman, A. \& Jaafar, N.I., 2014. Facebook: The enabler of online civic engagement for activists. Computers in Human Behavior, 32, pp.284-289. DOI: 10.1016/j.chb.2013.12.017

Wojcieszak, M. \& Smith, B., 2014. Will Politics be Tweeted? New media use by Iranian youth in, 2011. New Media \& Society, 16(1), pp.91-109. DOI: 10.1177/1461444813479594

Zizek, S., 2014. Event: A philosophical journey through a concept. London: Melville House.

\section{Other Sources}

Amnesty International, 2013. Gezi Park Protests: Brutal denial of the right to peacefully assembly in Turkey. Retrieved from https://www.amnestyusa.org/sites/default/files/eur440222013en.pdf. Accessed on Mar. 20 ${ }^{\text {th }}$.

Konda Research and Consultancy, 2014. Gezi Report Public Perception of the 'Gezi Protests': Who were the people at Gezi Park? Retrieved from http://konda.com.tr/wp-content/uploads/2017/03/KONDA_Gezi_Report.pdf Accessed on Mar. $20^{\text {th }}$.

Radikal, 2013. Polise emri ben verdim [I gave the order to the police], June 24. Retrieved from http://www.radikal.com.tr/turkiye/polise-emri-ben-verdim-1138828/. Accessed on Mar. 20 2019.

Taksim Dayanisma, 2013. We are Taksim Solidarity, We are Here! Digit.

\section{Artigos em Jornais}

Benhabib, S., 2013. Turkey's Authoritarian Turn. The New York Times, Jun. $3^{\text {th }}$. Retrieved from http://www.nytimes.com/2013/06/04/opinion/turkeys-authoritarian-turn.html? r=0 . Accessed on Mar. 29 2019. 
Letsch, C., 2014. A Year After the Protests: Gezi Park nurtures the seeds of a new Turkey. The Guardian, May $29^{\text {th }}$. Retrieved from https://www.theguardian.com/world/2014/may/29/gezi-park-year-after-protests-seeds-new-turkey. Accessed on Mar. $29^{\text {th }} .2019$.

\section{Protestos como "Acontecimentos": as lutas simbólicas nas manifestações de 2013 no Brasil e na Turquia}

RESUMO Introdução: O conceito de "acontecimento" oferece uma perspectiva interessante para a compreensão de disputas discursivas nos protestos e sobre eles. Por "acontecimento", entendemos rupturas da continuidade da experiência que alimentam disputas políticas pela reinterpretação de passados e futuros. Partindo do conceito e de sua utilidade para a leitura de disputas simbólicas, este artigo busca analisar os protestos de 2013 no Brasil e na Turquia. Investigamos como as razões a alicerçar tais protestos foram enquadradas e como esses enquadramentos mudaram ao longo do tempo, abrindo novas interpretações de passado e provendo novas possibilidades de imaginação do futuro. Materiais e Métodos: Dados foram gerados a partir de quatro páginas do Facebook, coletando mensagens postadas ao longo dos primeiros 30 dias de protestos em cada um dos países. No caso brasileiro, coletamos os posts de: (1) Passe Livre São Paulo (301.787 likes), o grupo que iniciou a onda de protestos; e (2) O Gigante Acordou (155.690 likes), um coletivo que emergiu durante os protestos, representando perspectivas nacionalistas. Ao todo, foram coletados 626 posts em ambas as páginas. No caso turco, analisaram-se posts que apareceram em: (1) Taksim Dayanismasi (82.479 likes), uma associação que teve papel significativo na organização e mobilização dos protestos do Gezi Park; e (2) Recep Tayyip Erdogan (6.957.408 likes), uma página pró-governo e essencialmente anti-protestos. Codificamos cada post indutivamente, enfocando, particularmente, o modo como eles enquadraram as causas dos protestos. Identificamos, então, a frequência de cada enquadramento nos 30 dias iniciais dos protestos e exploramos se, e como, isso se transformou ao longo do tempo. Resultados: A análise revelou a existência de viradas significativas na forma como as causas dos protestos foram enquadradas em ambos os países, mas com implicações distintas. Enquanto no Brasil, a "transformação de quadro" observada minou o foco inicial dos manifestantes, na Turquia, observa-se uma situação de "expansão do quadro", com a tematização de questões mais amplas como causas dos protestos, como a natureza autoritária do regime e as restrições a direitos democráticos no país. Discussão: O artigo oferece uma maneira de analisar protestos com base na lente conceitual do "acontecimento", esclarecendo o papel das mídias sociais no contexto das lutas simbólicas em torno dos protestos. Além disso, ele abre debate sobre as disputas de enquadramento a atravessar desdobramentos contemporâneos da democracia em ambos os países.

PALAVRAS-CHAVE: acontecimento; protestos; Gezi Park; Jornadas de Junho; Facebook.

This is an Open Access article distributed under the terms of the Creative Commons Attribution Non-Commercial License which permits unrestricted non-commercial use, distribution, and reproduction in any medium provided the original work is properly cited. 